\title{
Determination of optimum reaction and process control parameters of starch conversion in maltose syrup production
}

\section{Maltoz şurubu üretiminde nişasta dönüşümünün optimum reaksiyon ve proses kontrol parametrelerinin belirlenmesi}

\author{
Sema Nur ÇiNçik ${ }^{1}$, Fatih BALCl ${ }^{*}$ iD, Mustafa BAYRAM ${ }^{3}$ iD \\ 1,2,3 Gaziantep University. Faculty of Engineering. Department of Food Engineering. 27310. Gaziantep. Turkey. \\ ${ }^{1}$ https://orcid.org/0000-0003-3944-2482; ${ }^{2}$ https://orcid.org/0000-0002-9651-2064; ${ }^{3}$ https://orcid.org/0000-0001-6705-5899
}

To cite this article:

Cincik, S. N., Balcı, F. and Bayram, M. (2021). Determination of optimum reaction and process control parameters of starch conversion in maltose syrup production. Harran Tarım ve Gıda Bilimleri Dergisi, 25(2): 131150.

DOI: $10.29050 /$ harranziraat.881223

Address for Correspondence: Fatih BALCl

e-mail:

fbalci@gantep.edu.tr

Received Date:

16.02.2021

Accepted Date:

03.05.2021

(C) Copyright 2018 by Harran University Faculty of Agriculture. Available on-line at www.dergipark.gov.tr/harranziraat
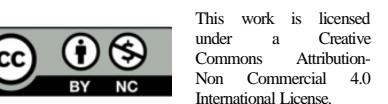

\section{ABSTRACT}

In maltose syrup production, one of the critical processing stages is the starch conversion process. During this process, the reaction time and enzyme concentrations are two important parameters to obtain the standard sugar spectrum. The purpose of this study is; i) to find optimum reaction time and enzyme concentrations during the starch conversion process, ii) to determine process control and dynamic parameters during the starch conversion process in the maltose syrup production. The different amounts of beta and alpha-amylase enzymes $(0.10,0.15,0.20$ and $0.25 \mathrm{ml}$ of $\beta$-amylase; $0.03,0.05,0.07$ and 0.09 $\mathrm{ml}$ of $\alpha$-amylase) were used to determine the optimum concentrations and time. $\mathrm{pH}$, Brix and the concentrations of sugars (dextrose, maltose, maltotriose (DP3) and high sugars (DPN)) were determined. It was found that the enzyme concentration, ratios of the enzyme used and reaction time significantly affect the starch conversion process. The mixture containing $0.20 \mathrm{ml} \beta$-amylase and $0.05 \mathrm{ml} \alpha$-amylase was determined as the optimum value $(P \leq 0.05)$. It was found that the maximum process gains were obtained at $0.1 \mathrm{ml} \beta$-amylase and $0.03 \mathrm{ml} \alpha$-amylase, $0.25 \mathrm{ml} \beta$-amylase and $0.03 \mathrm{ml} \alpha$-amylase, $0.2 \mathrm{ml} \beta$-amylase and $0.03 \mathrm{ml} \alpha$-amylase for dextrose, maltose, DP3 and DPN, respectively.

Key Words: Process control, Gain value, Starch conversion, Corn maltose syrup, $\alpha$-amylase, $\beta$-amylase

öz

Maltoz şurubu üretiminde kritik aşamalardan biri de nişasta dönüştürme işlemidir. Proses esnasında standart şeker spektrumunu elde etmek için iki önemli parametre reaksiyon zamanı ve enzim konsantrasyonlarıdır. Bu çalışmanın amacı maltoz şurubu üretiminde; i) Nişasta dönüşümü esnasında optimum reaksiyon ve enzim konsantrasyonunu bulmak, ii) Proses kontrol ve dinamik parametrelerinin tanımlanmasıdır. Optimum konsantrasyon ve zamanı belirlemek için farklı miktarlardaki alfa ve beta amilaz enzimleri ( $\alpha$-amilaz: $0.03,0.05,0.07$ ve $0.09 \mathrm{ml}$ ve $\beta$-amilaz: $0.10,0.15,0.20$ ve $0.25 \mathrm{ml}$ ) kullanılmıştır. Ph, briks ve şeker konsantrasyonları (dekstroz, maltoz, maltotrioz (DP3) ve yüksek şekerler (DPN) tanımlanmıştır. Bu çalışmada açıkça görülmüştür ki enzim konsantrasyonu, kullanılan enzim oranları ve reaksiyon zamanı nişastanın maltoza dönüşümünde önemli ölçüde etkilidir. Maltoz şurubunun optimum şeker değerlerine ulaşması için en ideal enzim karışım $0.20 \mathrm{ml} \beta$-amilaz ve $0.03 \mathrm{ml} \alpha$ amilazdır. Maksimum proses kazanımları dekstroz, maltoz, DP3 ve DPN için 0,1 $\mathrm{ml} \beta$-amilaz ve $0,03 \mathrm{ml} \alpha$-amilaz, $0,25 \mathrm{ml} \beta$-amilaz ve $0,03 \mathrm{ml} \alpha$-amilaz, $0,2 \mathrm{ml} \beta$-amilaz ve $0,03 \mathrm{ml} \alpha$-amilazdır.

Anahtar Kelimeler: Proses kontrolü, Kazanç değeri, Nişasta dönüşümü, Mısır maltoz şurubu, $\alpha$-amilaz, $\beta$-amilaz 


\section{Introduction}

Starch is one of the most common foods consumed by humans in the world. It is generally derived from corn, rice, wheat, potato and tapioca, (Johnson et al., 2009). Starch is found as a carbohydrate in the seeds and roots of many plants (Zeeman et al., 2010). Starch-containing foods are an important element of nutrition and among the foods consumed by humans. Also, starch is used as a different product e.g. chemically or enzymatically processed such as glucose, fructose syrup, etc.

Starch is accepted as a polymer of dextrose; consists of two noticeable fractions amylose and amylopectin. Despite differ depending on the starch type, it is generally in the range of $20-25 \%$ amylose and $75-80 \%$ amylopectin. Amylose and amylopectin have a similar molecular structure (Gough et al., 2020)

The amylose fraction comprises dextrose molecules combined at the 1-4 linkages to form a long, spiral chain. A chain of dextrose molecules which in the amylopectin fraction, combined at the 1-4 linkages, but with an additional straightchain attached at the 1-6 linkages. When using enzymes in maltose syrup production 1-4 and 1-6 linkages are very crucial because some enzymes can bind with this region. Therefore, the right choice of enzyme ratio is crucial for a successful process (Hull, 2010).

The starch industry uses $\alpha$ and $\beta$ amylase, isomerase, glucoamylase, pullulanase as enzymes. the $\alpha$-amylase enzyme binds to 1-4 linkages in gelled starch at dextrose and maltose production. $\beta$-amylase attacks the linkages to produce maltose, with little amounts of dextrose, just as $\alpha$ amylase (Hull, 2010).

Maltose syrup (called also "corn syrup") is produced using the technique of the hydrolysis of starch. Corn starch is the main raw material for maltose syrup production (Pontoh and Low, 1995). Moreover, maltose syrup is get from wheat, rice, cassava and barley (Hull, 2010). At the same time, It can be defined as maltose, glucose and other saccharides solutions obtained from edible starch (Eke-Ejiofor, 2015). Corn syrup gives foods to soften texture, add volume, prevent sugar from crystallization and enhancing aroma. Furthermore, they are used in pharmaceuticals, brewery and bakery products. Based on the hydrolysis technique of starch and to what extent the hydrolysis reaction is allowed to proceed, the different maltose syrups with different properties and uses are produced (Norman et al., 2001).

Industrially, corn maltose syrup is produced by enzymatic conversion of starch. Type 2-yellow dent-corn, which is removed from the cob is used for maltose syrup (Öktem et al., 2013). Approximately, $70 \%$ (d.b.) of kernel is starch and $10 \%$ (d.b.) is protein. During steeping, corn absorbs water. Soluble protein passes to water. The moisture of corn increase from 15 to $40 \%$ and the kernel swell and then soften. After steeping, corn $(40 \%)$ is milled and corn gluten meal, corn germ, corn protein and starch are separated from each other. The maltose process sets out the liquefaction step. Liquefaction step is done by using jet cooking, feed has 30-35\% dry solid starch slurry (Van Der Maarel et al, 2013). Starch is passed from jet cooking at $105{ }^{\circ} \mathrm{C}$ for $10 \mathrm{~min}$ and hold at the liquefaction step to work $\alpha$ amylase enzyme. Then, the $\beta$-amylase enzyme is added for the conversion of sugar. This step is called starch conversion and/or reaction. In this study, this step was evaluated based on enzyme concentration, reaction time, process control and dynamic (dead time, process time constant and gain).

For the further step in the production, there are filtration, ion exchange and evaporation. Corn protein is not completely separated from sugar therefore rotary vacuum filter is used for separating corn protein from sugar. Maltose syrup is passed through the ion exchange step for removing anions and cations. Finally, the concentration of maltose syrup is increased at the evaporation step. For commercial purposes, corn syrups are subdivided into four types based on dextrose equivalent; 20-38 Dextrose Equivalent (DE), 38-58 DE, 58-73 DE and $73 \mathrm{DE}$ or above 
(Blanchard, 1992). Sugar spectrum is determined by using HPLC (Polat et al., 2016).

As mentioned previously, the enzymatic conversion/reaction stage is very important for maltose syrup production. Since, polysaccharide chains are broken down to monomers, disaccharide and higher sugars during the reaction process. Temperature, enzyme type, substrate concentration and reaction time affect the maltose reaction. But, the information is very limited in the literature about the reaction (starch conversion) step.

In the starch industry, the reaction time is generally decided by the operators, in practice. The reaction time and initial enzyme concentration are the main decisive factors on the cost of the operation and product quality. If the reaction time is decreased, it will cause an increase in capacity and a decrease in energy cost. Additionally, process control and dynamics are critical for this step to obtain smooth production and product quality. Therefore, process gain (change in output/change in input), reaction time constant and dead time are the most important values for the process control of the dynamic systems (Altmann, 2005). In order to determine these values, the process reaction curve technique is maybe the best generally used method. It is simple to perform and provides an adequate model for many applications.

The purpose of this study was i) to find optimum reaction time and enzyme concentrations ( $\alpha$-amylase and $\beta$-amylase), ii) to determine process control and dynamic parameters which are, dead time values, process time constant and process gain during the starch conversion process in the maltose syrup production.

\section{Material and Methods}

\section{Materials}

The starch slurry was obtained from a controlled production line of Beşan Starch Plant (Gaziantep, Turkey). The moisture and starch contents of corn (Pioneer-2013) used in the starch production were measured as 15 and $70 \%$ (w.b.) (AOAC, 1990), respectively. $\beta$-amylase (E1), (1280 U/g Spezyme DBA-F, Genencor, Dupont, USA) and $\alpha$-amylase (E2), (32518 U/g Spezyme LT 300, Genencor, Dupont, USA) were used for the enzymatic conversion of starch during the reaction step.

\section{Experimental set-up}

The experimental set-up is given in Figure 1. The study was comprised of two parts as the plant and laboratory sections. The starch was produced and then cooked by using a jet-cooking under the controlled conditions $\left(105-106{ }^{\circ} \mathrm{C}, 10\right.$ mins). The starch content of slurry in the jetcooking operation was $37 \%$. The $\mathrm{pH}$ of the slurry was 5.7-6.0. After the jet cooking operation, the slurry was transferred to the liquefaction unit. In this step, dextrose equivalent (DE) and $\mathrm{pH}$ were reached 13 and 5.7, respectively. In order to stop the liquefaction operation, $\mathrm{pH}$ was adjusted to 2.0 by adding hydrochloric acid (Akay Kimya, Turkey). Then, the samples were stored for the experiments in a deep freezer (Beko, Turkey) at -5 ${ }^{\circ} \mathrm{C}$.

For the reaction/starch conversion stage, 2 liters of the sample was used for each run. $\mathrm{pH}$ and temperature were adjusted to 5.50-6.20 and 60 ${ }^{\circ} \mathrm{C}$, respectively. The $\mathrm{pH}$ adjustment was made by using $45 \%$ of $\mathrm{NaOH}$ (Akay Kimya, Turkey). The reaction was carried out in an agitator (RW 16 Basic, IKA, Japan) and a modified controllable water bath (BW20G, Jeo Tech, Korea).

The different amounts of enzymes (E1 and E2) were added for the reaction/starch conversion process (Table 1). The samples were collected every one hour for the analysis of dextrose, maltose, maltotriose (DP3), high-sugars (DPN), Brix, DE and $\mathrm{pH}$. 
Çinçik et al., 2021. Harran Tarım ve Gıda Bilimleri Dergisi, 25(2): 131-150

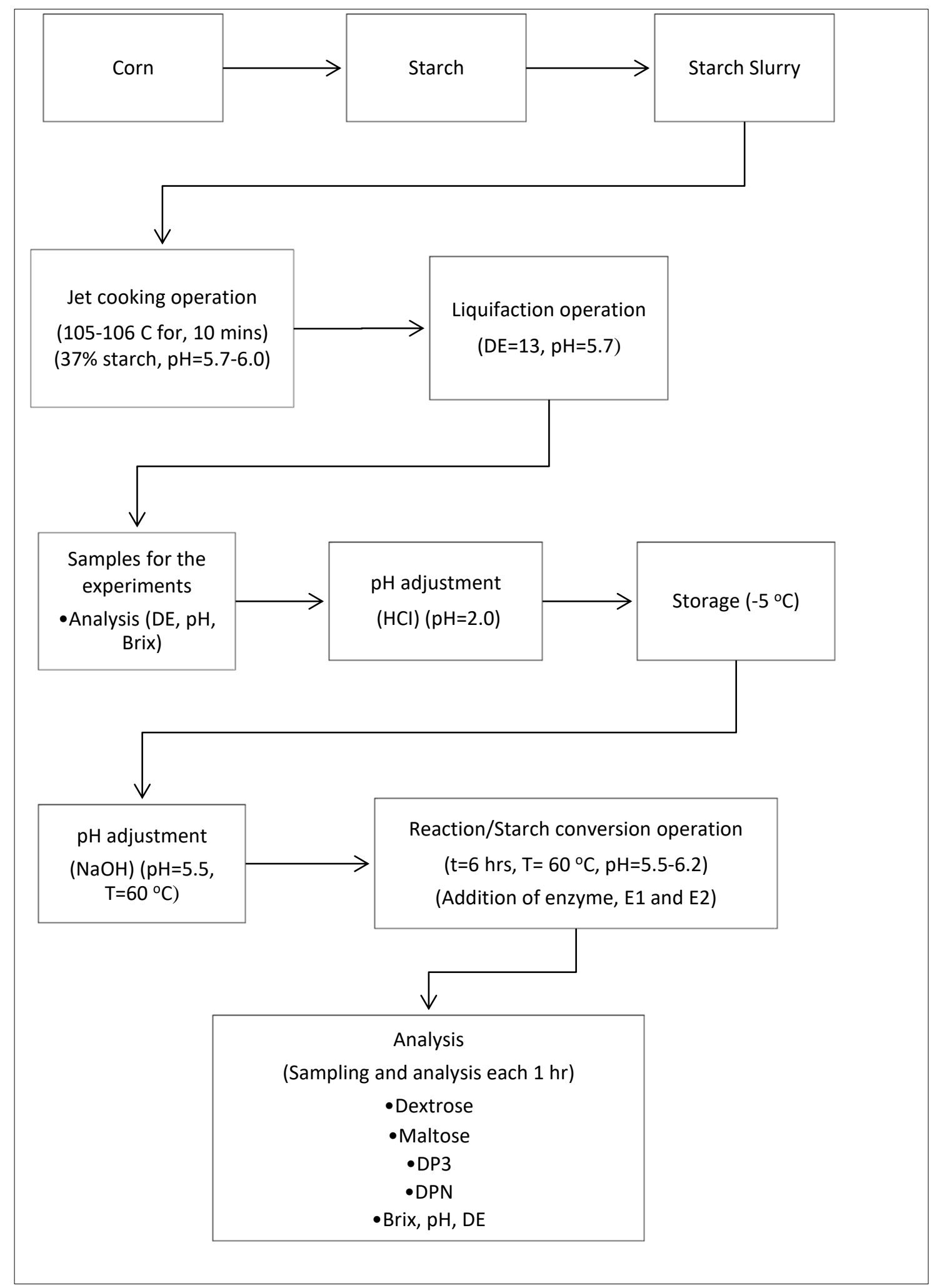

Figure 1. Experimental Set-up

Brix was measured using a refractometer (NAR-3T, Atago, Japan) at $20{ }^{\circ} \mathrm{C}$. The samples were filtered before the measurements.

\section{Determination of sugar profile}

The amount of dextrose, maltose, maltotriose (DP3) and high sugars (DPN) were determined by using HPLC (DGU-20A3, SIL-20 AHT, Reservoir tray, RID-10A, CTO-20A, Shimadzu, Japan) according to the method of Corn Refiner Associations, E-61 method (CRA, 2010). The sample (Brix=10) was prepared in a $1 \mathrm{ml}$ vial. After 20 minutes of resting, the sugar spectrum was determined. DPN, DP3, maltose and dextrose were determined at $7,8,9$ and $11^{\text {th }}$ mins, respectively. The pump flow rate and oven temperature were $0.5 \mathrm{ml} / \mathrm{min}$ and $80{ }^{\circ} \mathrm{C}$, respectively (CRA, 2010). 


\section{Determinations of $\mathrm{pH}$}

The Brix of the sample was adjusted to 40 before the measurement of $\mathrm{pH}$. $\mathrm{pH}$ was measured by using a $\mathrm{pH}$ meter (Orion Star Series, Thermo Scientific, Singapore).

\section{Determination of dextrose equivalent (DE)}

Dextrose equivalent (DE) was measured by using Lane and Eynon method (CRA, 2010).

Determination of process control and dynamic parameters (process gain, process time constant and dead time)

To determine the process control and dynamic variables (process gain, process time constant and dead time), the process reaction curve technique was used (Marlin, 2000). For this technique, there are two methods such as Method I and Method II, which both use graphical solutions. The graphical solution for the process reaction technique decides the parameters for a first-order with a dead-time model. The version defines $X(s)$ denoting the input and $Y(s)$ denoting the output (Eq. 1). Both $X$ and $Y$ expressed in aberration factors;

$\frac{Y(s)}{X(s)}=\frac{K p e^{-\theta s}}{\tau s+1}$

where $\mathrm{Kp}, \theta, \tau$ and $\mathrm{s}$ are process gain, dead time, process time constant and Laplace frequency value, respectively.

The first method (Method I) concerted by Ziegler et al. (1942) uses graphical calculations. The average rates decided from the plot are the value of the input change $(\delta)$, the steady-state change in the output $(\Delta)$ and the maximum slope of the output-versus-time plot (S). The values from the plot can be described to the model parameters about the subsequent relationships for a first-order-with-dead-time model. The common model for a step within the input with $t$ $\geq \theta$ is;

$Y^{\prime}(t)=K p * \delta\left[1-e^{-\frac{(t-\theta)}{\tau}}\right]$ can be designated to be;

$\frac{d Y^{\prime}(t)}{d t}=\frac{d}{d t}\left\{K p * \delta\left[1-e^{-\frac{t-\theta}{\tau}}\right]\right\}=\frac{\Delta}{\tau} e^{-(t-\theta) / \tau}$

The max slope at $\mathrm{t}=\theta$. That, $\mathrm{S}=\Delta / \tau$. Thus, the variables can be described as;

$K p=\Delta / S$

$\tau=\Delta / S$

where $\theta$ is the intercept of maximum slope with initial value, $\mathrm{Y} 2(\mathrm{t})$ is output value versus time.

The second method, Method II also uses the graphical solution. The average rates examined from the graph are the steady-state change in the output $(\Delta)$, the significance of the input change ( $\delta)$ and the times where the output levels up $28 \%$ and $63 \%$ of its final value. The chart can be associated with the model parameters using the common definition Eq. 2. Choice of any two values of time can examine the unexplained specifications, $\theta$ and $\tau$. The ordinary times are preferred where the transient response is changing rapidly so that the model parameters can be exactly stated despite measurement noise (Smith, 1972). The definitions are;

$Y(\theta+\tau)=\Delta\left(1-e^{-1}\right)=0.632 \Delta$

$Y(\theta+\tau / 3)=\Delta\left(1-e^{-1 / 3}\right)=0.283 \Delta$

Thus, the values of time at which the output reaches 28.3 and 63.2 percent of its final value were used to calculate the parameters.

$$
\begin{array}{ll}
t_{28 \%}=\theta+\frac{\tau}{3} & t_{63 \%}=\theta+\tau \\
\tau=1.5\left(t_{63 \%}-t_{28 \%}\right) & \theta=t_{63 \%}-\tau
\end{array}
$$

To sketch the graphs, the experimental data was modeled by using the Sigmoidal model (Sigmoid, 3 Parameter) (Eq. 10) (Sigmaplot Software, Sigmaplot Co., Cornwall, Canada).

$$
f=a /\left(1+\exp \left(-\left(x-x_{0}\right) / b\right)\right)
$$

where $f, a, b, x$ and $x_{0}$ are parameters of the model. 


\section{Statistical analysis}

A standard procedure of the analysis of variance (One-way Anova) ( $\alpha \leq 0.05)$ was performed to the data to assess the influence of the amount of enzyme and time on the sugar spectrum. Statistically significant correlations were decided as regards the Pearson coefficient $(P \leq 0.01)$ All statistical analyses were applied using SPSS software (ANOVA, SPSS Inc., Chicago, IL). The experiments were two replicated and the measurements were duplicated.

\section{Results and Discussion}

In the starch industry, the optimum maltose sugar spectrum is normally reached within 6 hours in the reaction step. Enzymes used during this step are quite costly. To reduce this cost, it is necessary to determine the optimum enzyme mixture. In the present study, the optimum enzyme mixture of $\beta$-amylase and $\alpha$-amylase was determined by using different concentrations shown in Table 1. The experimental and statistical data obtained in the study conducted to find the ratio of the ideal mixture of these two enzymes to determine the optimum enzyme mixture are presented in Table 2. Besides, during the conversion of starch to maltose in the reaction step, it was determined the dextrose, maltose, maltotriose (DP3), higher sugars (DPN), Brix and $\mathrm{pH}$ for each enzyme mixture for each hour. The overall experimental results are shown in Figure 6-9. The correlations among the parameters were analyzed statistically as Pearson coefficients and shown in Table 2.

Table 1. Concentration of enzymes (E1: $\beta$-amylase, E2: $\alpha-$ amylase)

\begin{tabular}{lllc}
\hline Run No & E1 $(\mathrm{ml})$ & E2 $(\mathrm{ml})$ & Ratio (E2/E1) \\
\hline 1 & 0.10 & 0.03 & 0.30 \\
2 & 0.10 & 0.05 & 0.50 \\
3 & 0.10 & 0.07 & 0.70 \\
4 & 0.10 & 0.09 & 0.90 \\
\hline 5 & 0.15 & 0.03 & 0.20 \\
6 & 0.15 & 0.05 & 0.33 \\
7 & 0.15 & 0.07 & 0.47 \\
8 & 0.15 & 0.09 & 0.60 \\
\hline 9 & 0.20 & 0.03 & 0.15 \\
10 & 0.20 & 0.05 & 0.25 \\
11 & 0.20 & 0.07 & 0.35 \\
12 & 0.20 & 0.09 & 0.45 \\
\hline 13 & 0.25 & 0.03 & 0.12 \\
14 & 0.25 & 0.05 & 0.20 \\
15 & 0.25 & 0.07 & 0.28 \\
16 & 0.25 & 0.09 & 0.36 \\
\hline
\end{tabular}

Table 2. Pearson correlation test coefficients

\begin{tabular}{|c|c|c|c|c|c|c|c|}
\hline & E1 & E2 & $\begin{array}{l}\text { Time } \\
\text { (hr) }\end{array}$ & $\begin{array}{c}\text { Dextrose (\%, } \\
\mathrm{g} / \mathrm{g})\end{array}$ & $\begin{array}{c}\text { Maltose (\%, } \\
\mathrm{g} / \mathrm{g})\end{array}$ & $\begin{array}{c}\text { DP3 } \\
(\%, g / g)\end{array}$ & $\begin{array}{c}\text { DPN } \\
(\%, g / g)\end{array}$ \\
\hline $\mathrm{E} 1(\mathrm{ml})$ & 1 & & & & & & \\
\hline $\mathrm{E} 2(\mathrm{ml})$ & 0.00 & 1 & & & & & \\
\hline Time (hr) & 0.00 & 0.000 & 1 & & & & \\
\hline Dextrose $(\%, \mathrm{~g} / \mathrm{g})$ & $-613 * *$ & $0.156 * *$ & $0.476^{* *}$ & 1 & & & \\
\hline Maltose $(\%, \mathrm{~g} / \mathrm{g})$ & $0.550 * *$ & 0.007 & $0.748^{* *}$ & -0.006 & 1 & & \\
\hline DP3 $(\%, g / g)$ & $-0.225^{* *}$ & $0.271 * *$ & $0.765^{* *}$ & $0.540 * *$ & $0.556 * *$ & 1 & \\
\hline DPN $(\%, g / g)$ & $-0.371 * *$ & -0.080 & $-0.830 * *$ & $-0.170 * *$ & $-0.961 * *$ & $-0.725^{* *}$ & 1 \\
\hline
\end{tabular}

Changes in the amount of dextrose, maltose, DP3 and DPN during the starch conversion reaction

The starch from the different sources could be converted into glucose, maltose and maltodextrins. One of the most widely used in the food industry is maltose, especially in the brewing industry (Piddocke et al., 2009). The starch chain can be converted into dextrin by a few groups of amylases (BeMiller and Huber, 2007; Synowiecki, 2007). The $\alpha$-amylases hydrolyze the starch molecule into smaller molecules. It is used to advance the gelatinization process, in enzymatic starch extraction, to decrease medium viscosity and in saccharification processes (BeMiller et al., 2007; Synowiecki, 2007). $\beta$-amylases (EC 3.2.1.2) are liable for partial hydrolysis of starch.

$E 1$ is the $\beta$-amylase enzyme responsible for the 
hydrolysis of starch. E2 is an a-amylase enzyme that decreases medium viscosity. When the changes in the amount of dextrose, maltose, DP3 and DPN were analyzed during the starch conversion stage, it was found that the amount of dextrose significantly $(P \leq 0.05)$ changed. The minimum $(0.30 \%)$ and maximum $(2.74 \%)$ amount of dextrose were obtained at Run 5 (E1=0.15+E2=0.03) (Figure 7) and Run 3 (Figure 6) $(E 1=0.10+E 2=0.07)$, respectively. Figure 2 shows that not only E1 and E2 enzymes affect the dextrose amount and time also affects the dextrose concentration.

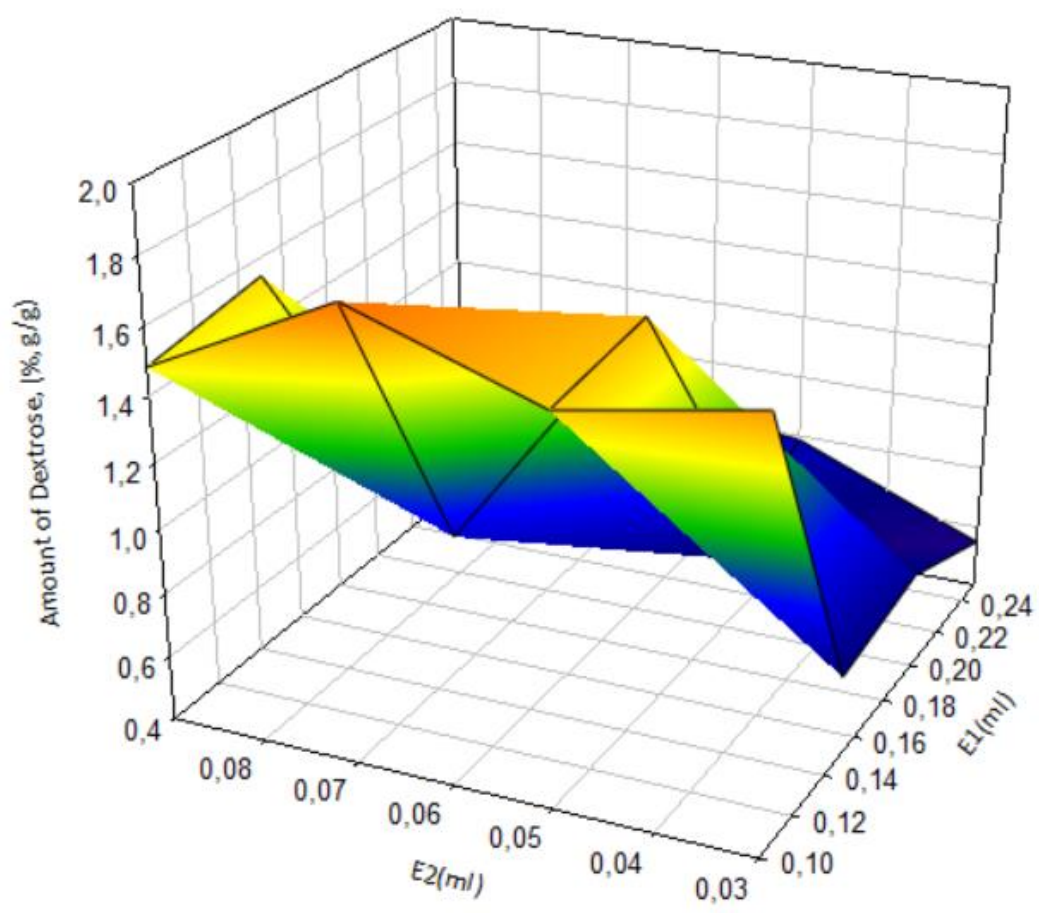

Figure 2. Three-dimensional illustration of effect of different enzyme concentrations (E1:E2) on dextrose

Statistical analysis showed that E1xE2, E2xTime and E1xE2xTime interactions had a significant $(P \leq 0.05)$ effect on the amount of dextrose. According to the results of the Pearson correlation test $(P \leq 0.01)$, the amount of dextrose changed by using alpha (within the range 0.030.09 ) and beta-amylases (within the range 0.10.25) during the starch conversion operation. Besides, the correlations between E1, E2 and time were significant $(P \leq 0.01)$ as shown in Table 2 . As a result of both analyses, the dextrose concentration was affected by alpha and betaamylase enzymes and time.

When the change in the amount of maltose was evaluated during the starch conversion stage by using the different enzyme concentrations and ratios (Figure 3 ), it was determined that there was a significant $(P \leq 0.05)$ increase in the amount of maltose during the starch conversion. According to the Pearson correlation analysis, the amount of maltose increased with E1 concentration; however, E2 concentration had not significant $(P>0.05)$ effect (Table 2 ) on the amount of maltose. The maximum amount of maltose was obtained at $\mathrm{E} 1=0.25+\mathrm{E} 2=0.03$ (Run 13) (Figure 9) while the minimum amount of maltose was obtained at $E 1=0.1+E 2=0.07$ (Run 3). It was also found that E1, time, E1xtime and E1xE2 were significantly $(P \leq 0.05)$ effective on the maltose concentration. It is obvious that the E1 enzyme and time were effective in the maltose concentration. The effectiveness of E1 can be explained that it is beta-amylase as a debranching enzyme that converts polysaccharides to monosaccharides based on Hull (2010). 


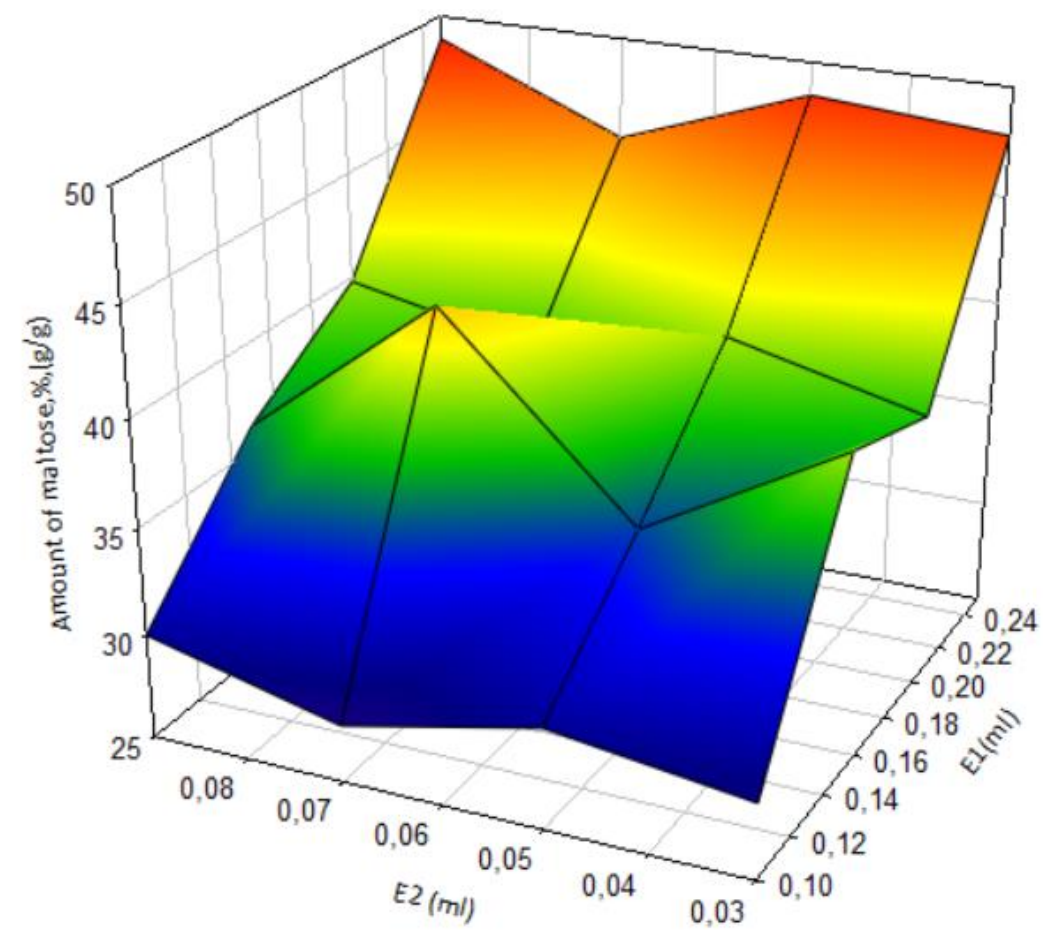

Figure 3. Three-dimensional illustration of effect of different enzyme concentrations (E1:E2) on maltose

In a similar study on the conversion of barley starch, MacGregor et al. (1999) applied response surface methodology to examine $\alpha$ and $\beta$ amylase levels and dextrinase enzymes. These enzymes are required for adequate modification of starch to fermentable sugars during the mashing process. Micro-scale mashes clarified from barley starch and malt enzymes. They were treated in a mash bath and solubilized starch, reducing sugars (neocuproine assay) and fermentable sugars (anion exchange HPLC) analyses were done for mash liquors. They found that fermentable sugars in the mash liquor were exactly related to reducing sugars and the percentage of starch solubilized during mashing. The addition of limit dextrinase to the mashes caused an important rising in levels of fermentable sugars and limit dextrinase displayed a synergistic effect with combined high levels of beta-amylase in increasing levels of maltose in the mash liquor. The obtained data and literature information support each other. As the $\beta$-amylase level increases in the reaction, the number of maltose increases. Similar to dextrose and maltose, the amount of DP3 significantly ( $P \leq 0.05)$ changed (Figure 4). It was found that E1, E2 and time had a significant effect $(P \leq 0.01)$ on the change of DP3 (Table 2). Additionally, there was a correlation between dextrose, maltose and DP3. The maximum and minimum amount of DP3 were 21.86 and $6.78 \%$ at $3^{\text {rd }}$ hour ( $E 1=0.15+E 2=0.07$ ) and at $1^{\text {st }}$ hour $(E 1=0.20+E 2=0.03)$, respectively. According to the statistical analysis, there was a significant interaction $(P \leq 0.05)$ such as $E 1 x$ Time, E1xE2, E2xTime and E1xE2xTime. An increase in the concentration of $E 1$ and $E 2$, and also reaction time had a reverse effect on the concentration of DP3 (Table 2). 


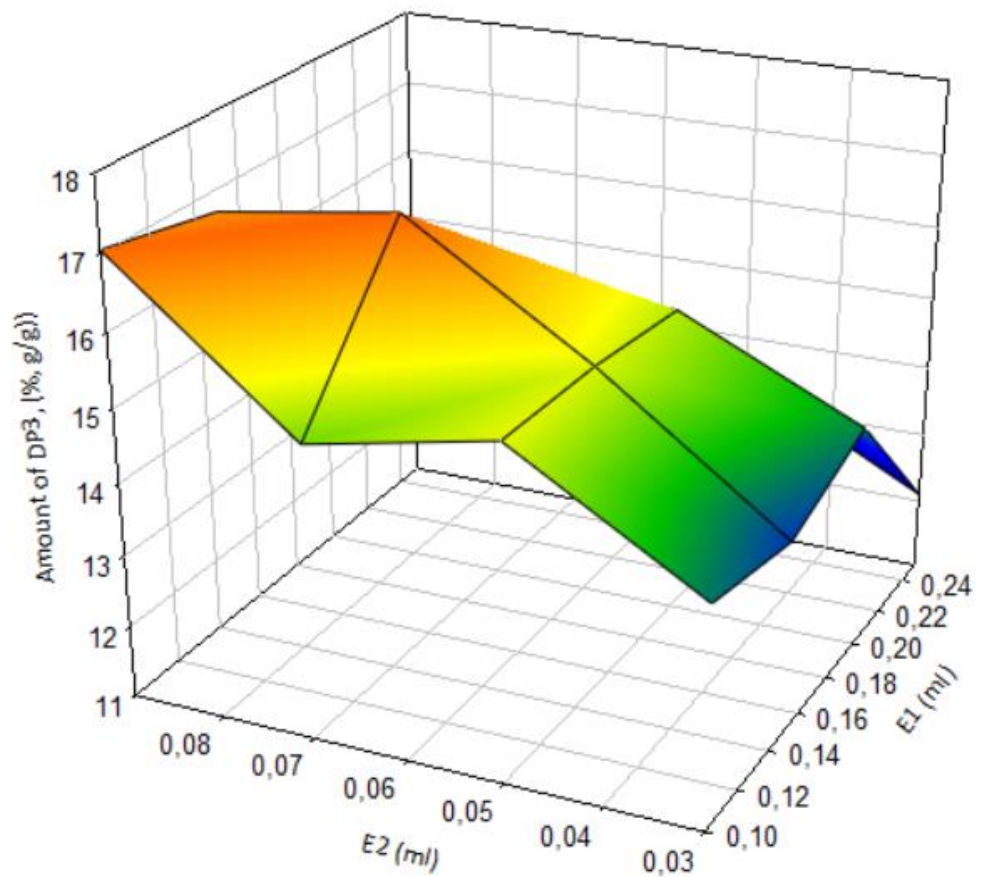

Figure 4. Three-dimensional illustration of effect of different enzyme concentrations (E1:E2) on DP3

The minimum amount of DPN (high sugar) was also found as $28.82 \%$ at the $6^{\text {th }}$ hour $(0.25 \mathrm{ml}$ $\mathrm{E} 1+0.07 \mathrm{ml} \mathrm{E} 2$ enzyme) and its maximum amount was determined as $77.74 \%$ at the first hour $(0.1$ $\mathrm{ml} \mathrm{E1+0.07} \mathrm{E2)} \mathrm{(Figure} \mathrm{5).} \mathrm{E1,} \mathrm{E2,} \mathrm{time,} \mathrm{E2xTime,}$ E2xE1, E1xTime, E1xE2xTime had a significant
$(P \leq 0.05)$ effect on the high sugar concentration. E1 and E2 enzymes had a reverse effect on DPN concentration according to Pearson correlation. Besides, time, dextrose, maltose and DP3 concentrations have a reverse effect on DPN concentrations $(P \leq 0.05)$.

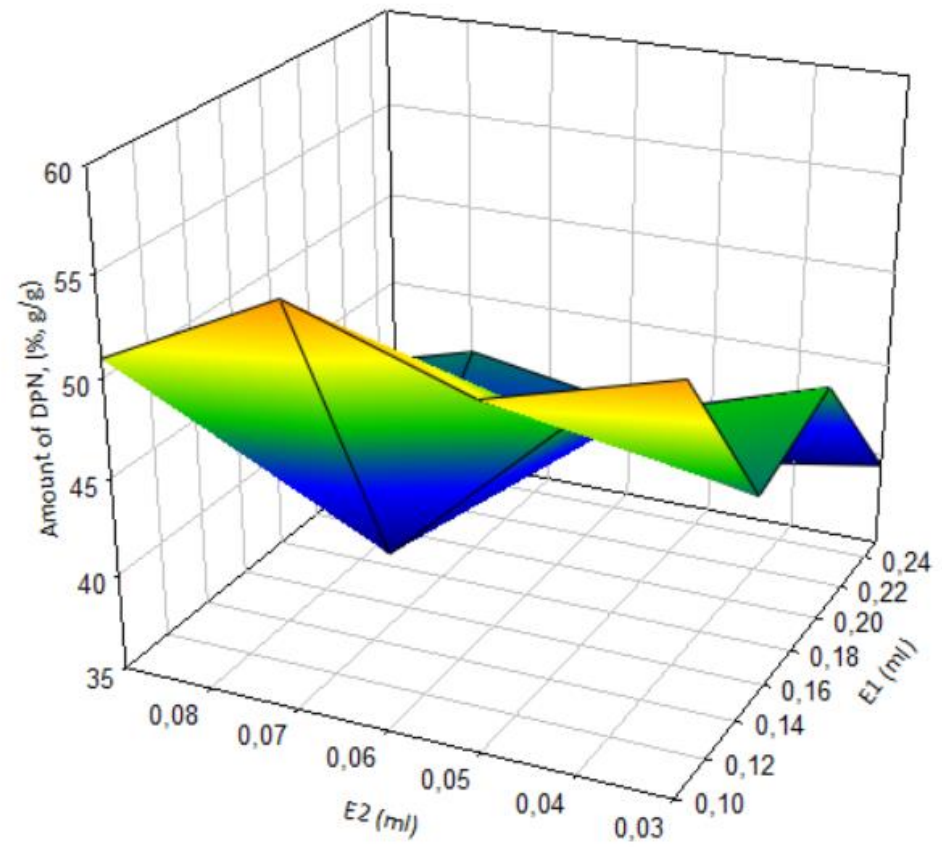

Figure 5. Three-dimensional illustration of effect of different enzyme concentrations (E1:E2) on DPN

In the present study, additionally, besides the enzyme amounts, the enzyme ratios (E2/E1) (Table 1) were evaluated to find their effect on the amount of dextrose, maltose, DP3 and DPN. The minimum amount of dextrose was found at
0.12 of enzyme ratio (E2/E1) in $1^{\text {st }}$ hour (Run 13; $0.25 \mathrm{ml} \mathrm{E1}+0.03 \mathrm{ml} \mathrm{E2}$ ) (Table 1). However, the maximum amount of dextrose was found at 0.70 of enzyme ratio (E2/E1) at the $6^{\text {th }}$ hour (Run 3; $0.10 \mathrm{ml} \mathrm{E1+0.07} \mathrm{ml} \mathrm{E2)} \mathrm{(Table} \mathrm{1).} \mathrm{It} \mathrm{indicated}$ 
while increasing the E1 enzyme that the amount of dextrose did not increase. On the other hand, the E2 enzyme was important for increasing the dextrose concentration. Also, time proportionally affected the amount of dextrose.

The minimum and maximum amounts of maltose were determined at 0.7 and 0.12 of enzyme ratios (E2/E1), (Run 3; $0.10 \mathrm{ml} \mathrm{E1+0.07}$ $\mathrm{ml} \mathrm{E2}$, Run $13 ; 0.25 \mathrm{ml} \mathrm{E1}+0.03 \mathrm{ml} \mathrm{E2}$ ) at $1^{\text {st }}$ and $6^{\text {th }}$ hours, respectively (Table 1 ). E1 enzyme and time had a positive effect on the maltose concentration. On contrary, the E2 enzyme had no important effect on the maltose. Besides, the minimum and maximum amounts of DP3 were determined at 0.15 and 0.47 of enzyme ratios (E2/E1), (Run 9; 0.20 E1+0.03 E2, Run 7; 0.15 $\mathrm{E} 1+0.09 \mathrm{E2}$ ) at $1^{\text {st }}$ and $6^{\text {th }}$ hours (Figure $7-8$ ), respectively. The minimum and maximum amounts of DPN were determined at 0.28 and 0.47 enzyme ratios (E2/E1), (Run 15; $0.25 \mathrm{ml}$ $\mathrm{E} 1+0.07 \mathrm{ml} \mathrm{E2}$, Run 3; $0.10 \mathrm{ml} \mathrm{E1+0.07} \mathrm{ml} \mathrm{E2)} \mathrm{at}$ $1^{\text {st }}$ and $6^{\text {th }}$ hours (Figure 6 and 9), respectively. All of these data indicate that time positively affects dextrose, maltose and DP3 concentrations, but reverse affects on DPN concentration. Additionally, E1 and E2 enzymes show a positive effect on all of the sugars.

There are different starch sources in the industry and they are nearly used the same production method. The results of the present study are also helpful for the other starch processing. In order to evaluate the suitability of this study to the other starch applications, the study of Lin et al. (2013) is important. In their studies, the rice starch sample was converted into maltose syrup for comparison with the corn starch sample. A amylase enzyme was used for conversion at the liquefaction step (EC 3.2.1.1). Also, pullulanase (EC 3.2.1.41) and $\beta$-amylase (EC 3.2.1.2) were used at the saccharification step. Scanning electron micrographs were used for determining the structure of the rice and corn starch samples. The final data showed that the granule range of the rice starch was considerably small and the optimal liquefaction time of rice starch short according to the corn starch sample.
The main impurities of the rice starch sample which are isomaltose and higher oligosaccharides were considerably low according to the sample of corn $(P \leq 0.05)$ and starch of rice to maltose conversion was similar to corn starch. It was showed that rice starch was used as an alternative to corn starch. Therefore, the results of the present study can also be better used in rice starch production.

Chemical, thermal and enzymatic treatment can be a new process for hulled barley as an applicable starch source. These processes were developed by Kim et al. (2011). The aim of this treatment is both starch and lignocellulosic polysaccharides in hulled barley grains convert into fermentable sugars at the same time no need for milling and bran separation. In that study, hulled barley grains were processed in a 63-ml flow-through packed-bed stainless steel reactor at 0.1 and 1.0 (wt.) \% sulfuric acid and $110-170{ }^{\circ} \mathrm{C}$. After this step, conversion of starch and lignocellulose in the barley into sugar was carried out by using alpha-amylase, glucoamylase, cellulase and beta-glucosidase. Barley grains in the pre-treated which have starch and nonstarch polysaccharides were performed to fermentable sugars. Hulled barley grains were converted into fermentable sugars with the available glucose and xylose. The 1.0 (wt.) \% sulfuric acid $110{ }^{\circ} \mathrm{C}$ conditions were used to obtain maximum efficiency from fermentable sugars. 


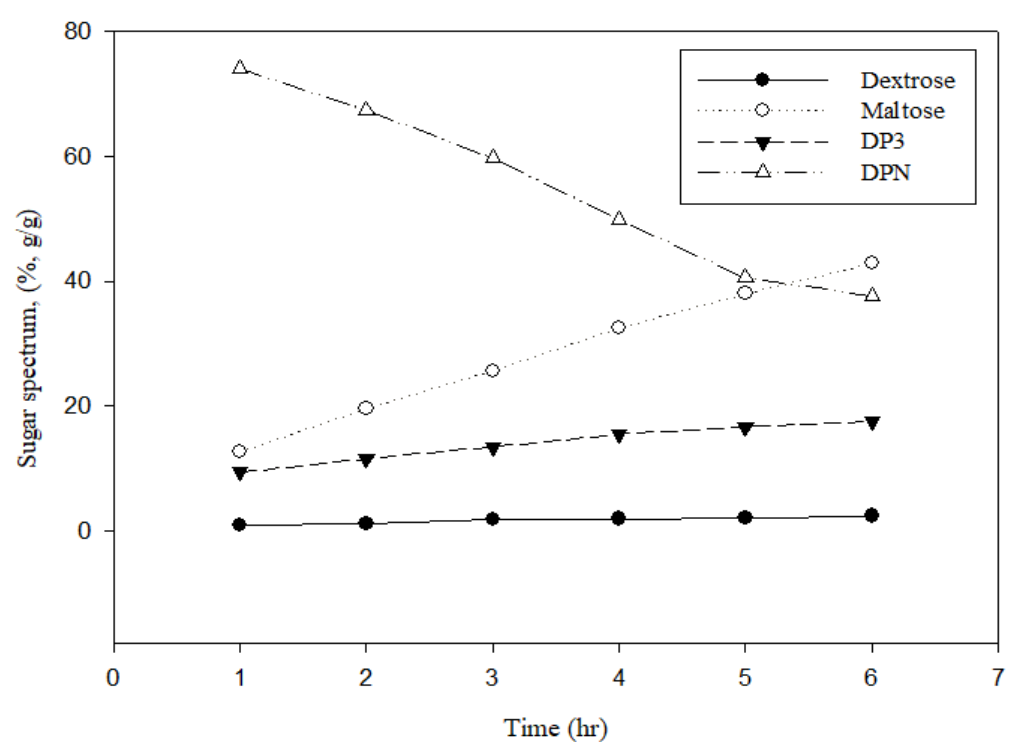

(a) Run 1: $E 1=0.10 \mathrm{ml}+\mathrm{E} 2=0.03 \mathrm{ml}$

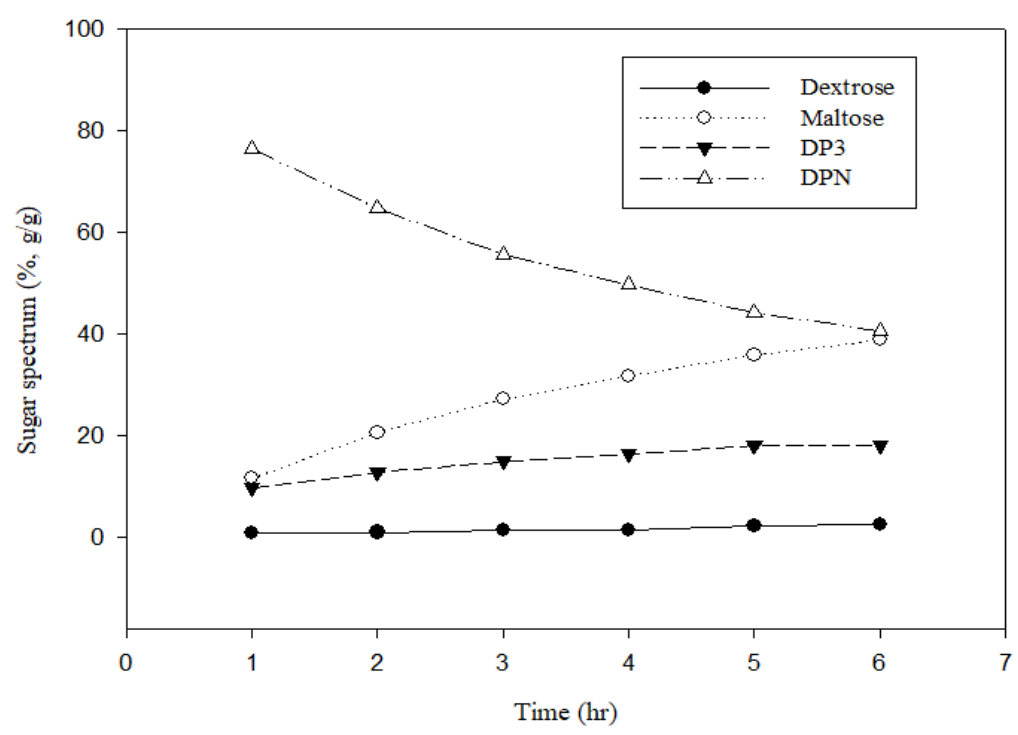

(c) Run 3: $E 1=0.1 \mathrm{ml}+\mathrm{E} 2=0.07 \mathrm{ml}$

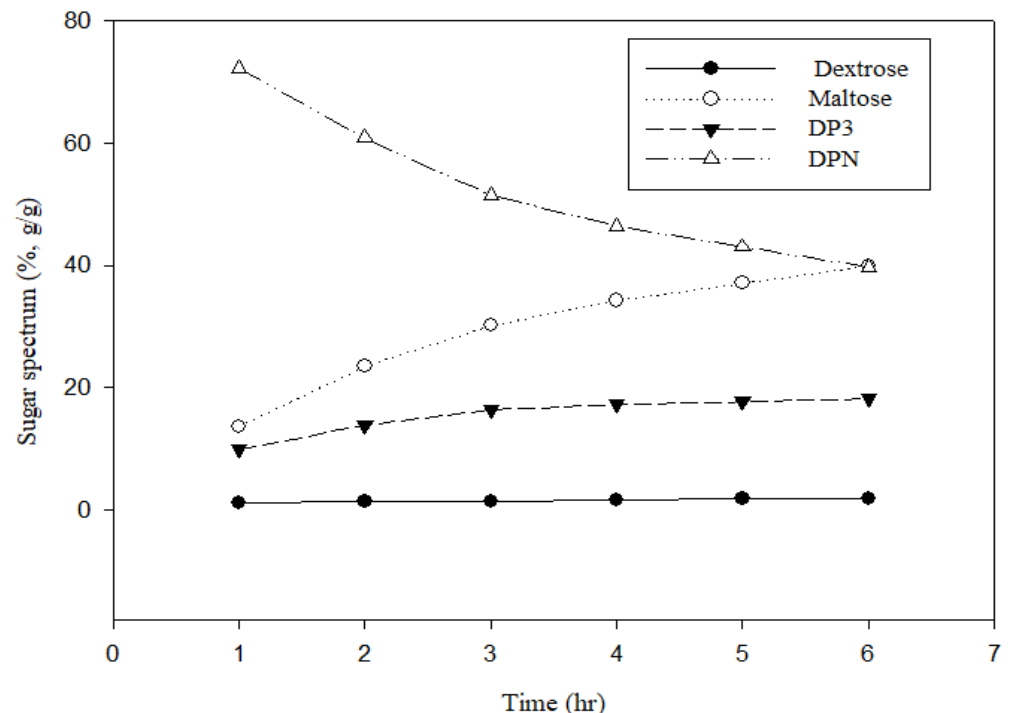

(b) Run 2: $\mathrm{E} 1=0.10 \mathrm{ml}+\mathrm{E} 2=0.05 \mathrm{ml}$

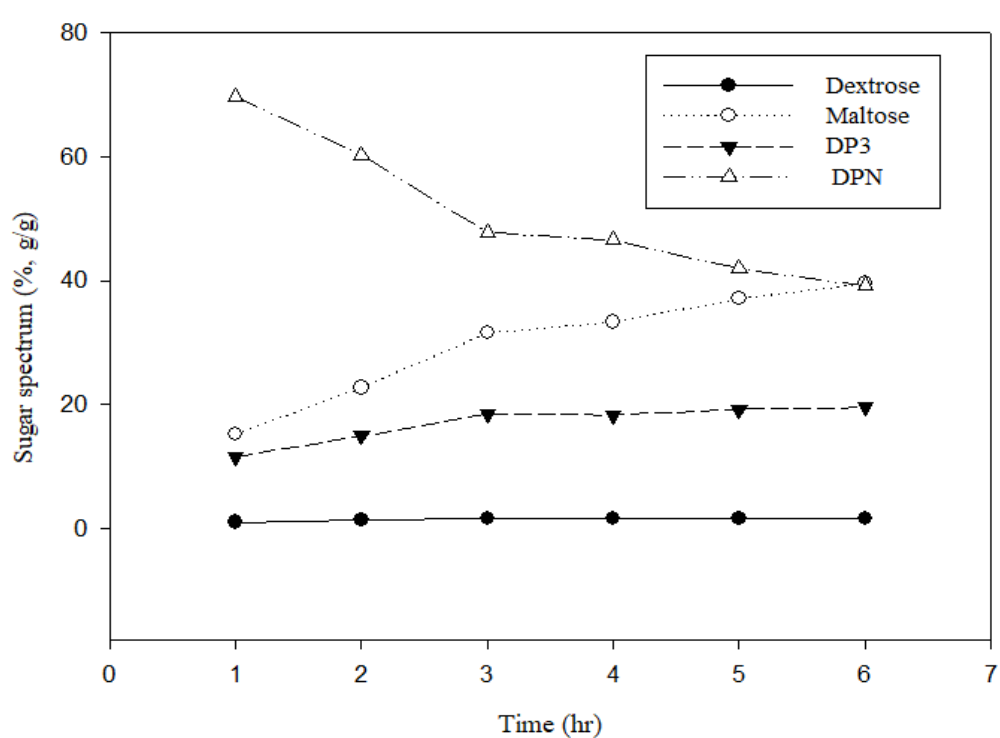

(d) Run 4: $\mathrm{E} 1=0.10 \mathrm{ml}+\mathrm{E} 2=0.09 \mathrm{ml}$

Figure 6. Different E2 concentrations; (a): $0.03 \mathrm{ml}$, (b): $0.05 \mathrm{ml}$, (c): $0.07 \mathrm{ml}$ and (d): $0.09 \mathrm{ml}$ mixed with E1: 0.10 


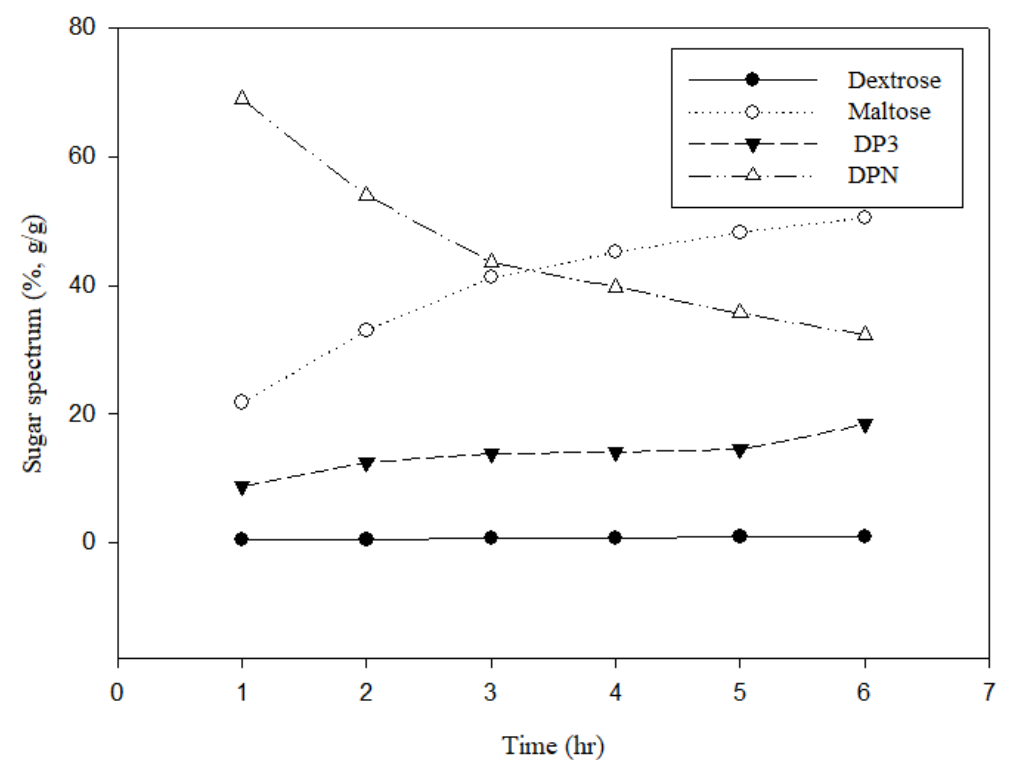

(a) Run 5: E1 $=0.15 \mathrm{ml}+\mathrm{E} 2=0.03 \mathrm{ml}$

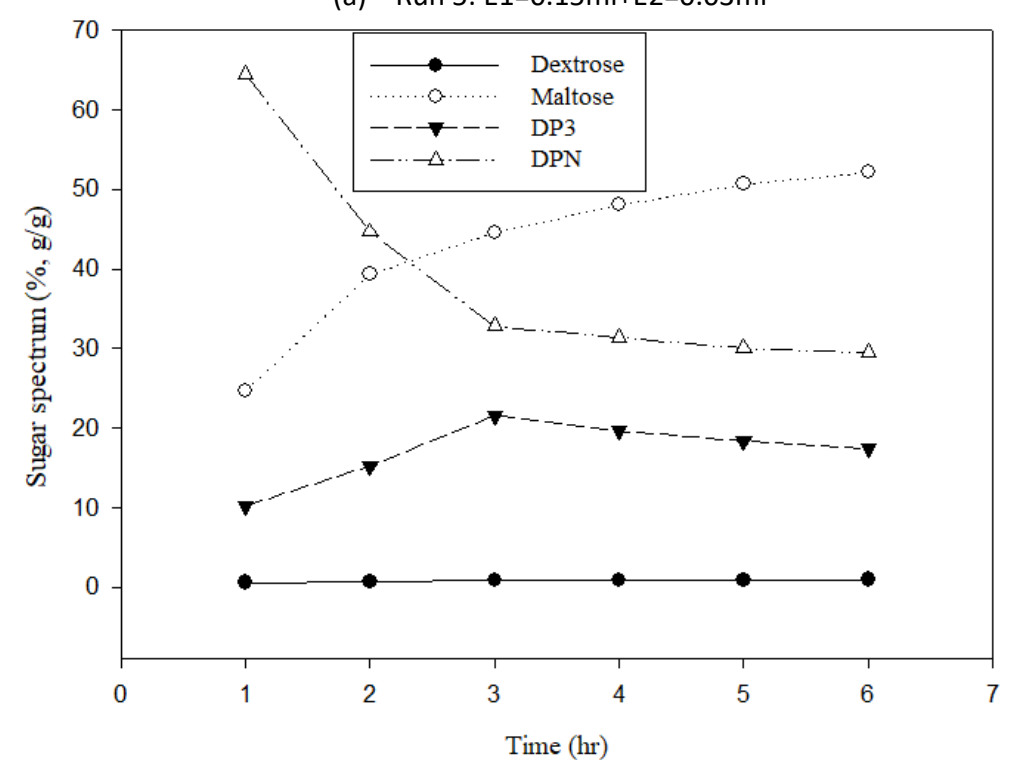

(c)Run 7: $\mathrm{E} 1=0.15 \mathrm{ml}+\mathrm{E} 2=0.07 \mathrm{ml}$

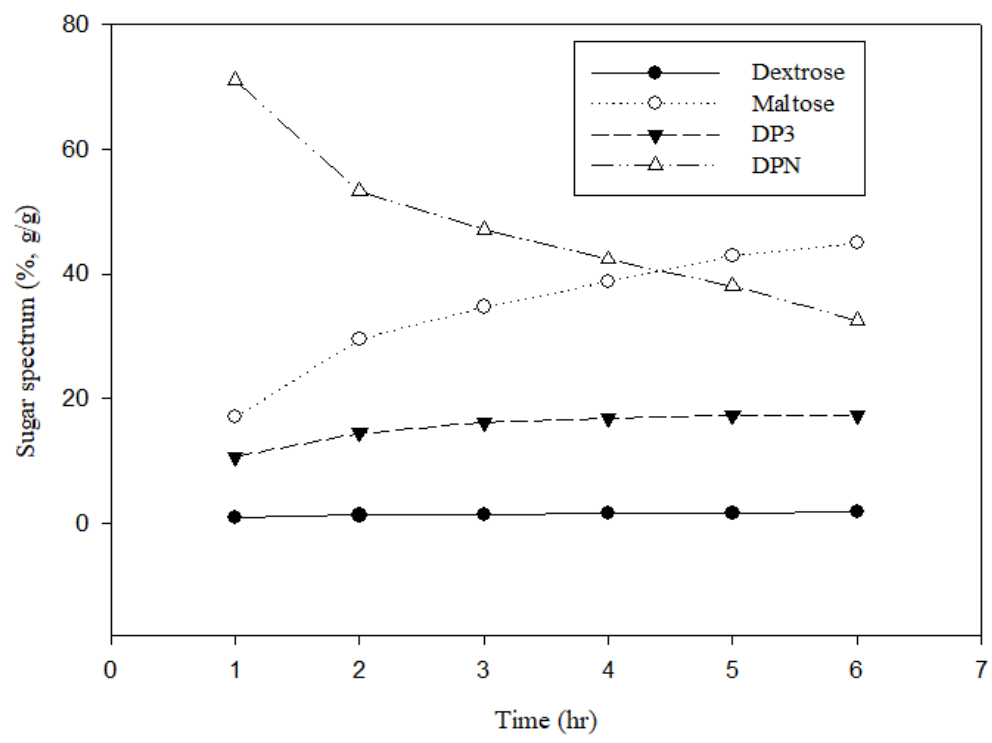

(b) Run 6: $\mathrm{E} 1=0.15 \mathrm{ml}+\mathrm{E} 2=0.05 \mathrm{ml}$

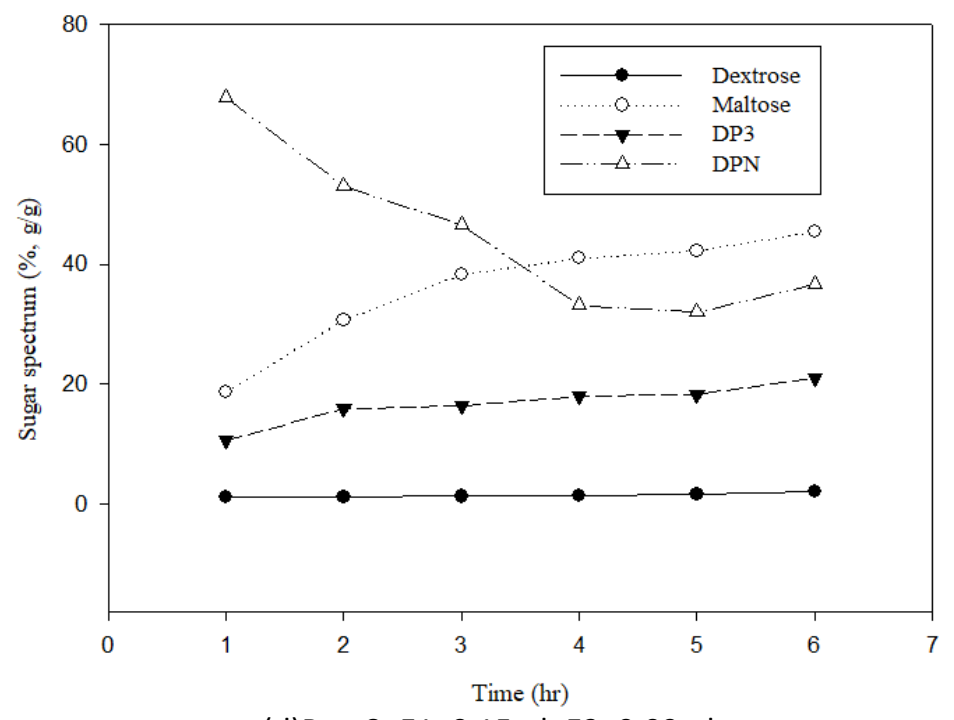

(d)Run 8: $E 1=0.15 \mathrm{ml}+\mathrm{E} 2=0.09 \mathrm{ml}$

Figure 7. Different E2 concentrations. (a): $0.03 \mathrm{ml}$, (b): $0.05 \mathrm{ml}$, (c): $0.07 \mathrm{ml}$ and (d): $0.09 \mathrm{ml}$ mixed with E1: $0.15 \mathrm{ml}$ 


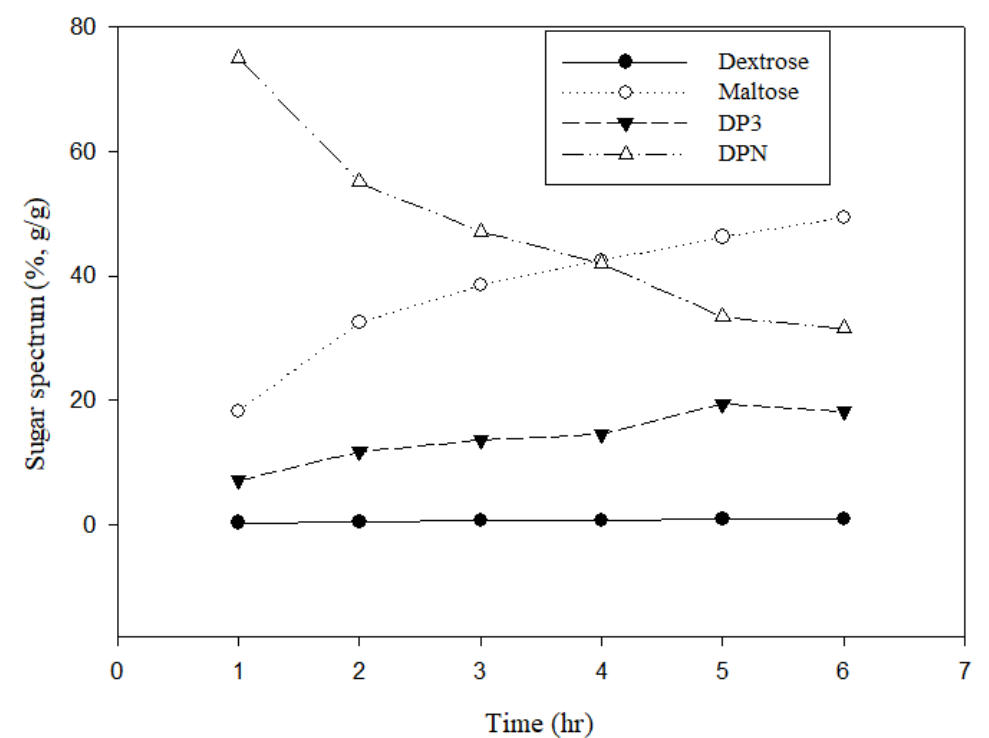

(a) Run 9: $\mathrm{E} 1=0.20 \mathrm{ml}+\mathrm{E} 2=0.03 \mathrm{ml}$

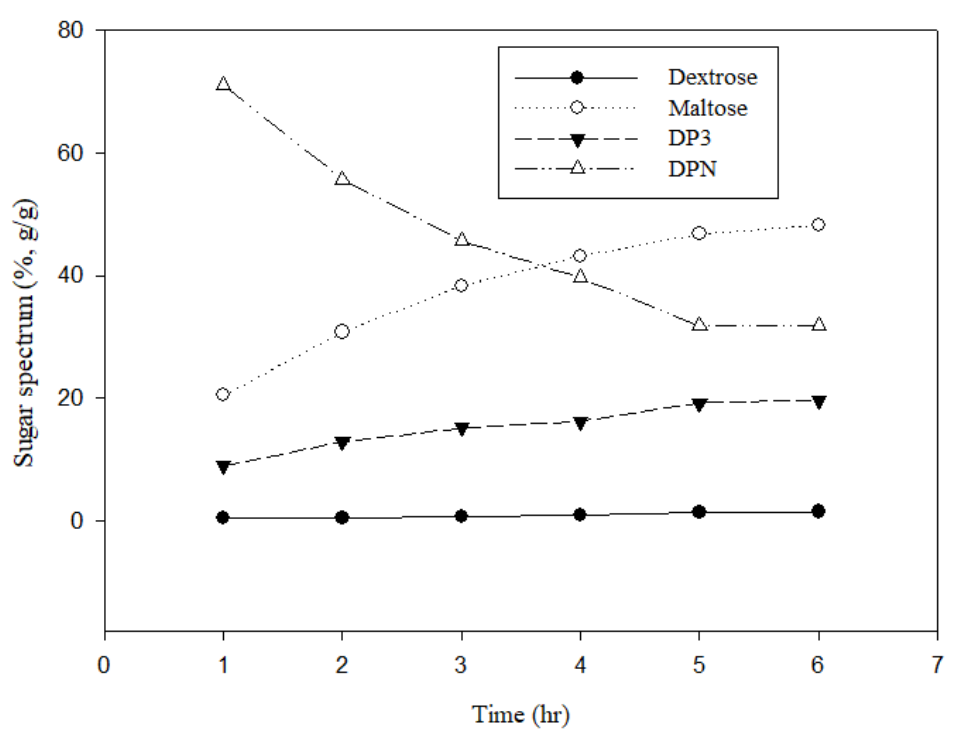

(c) Run 11: $\mathrm{E} 1=0.20 \mathrm{ml}+\mathrm{E} 2=0.07 \mathrm{ml}$

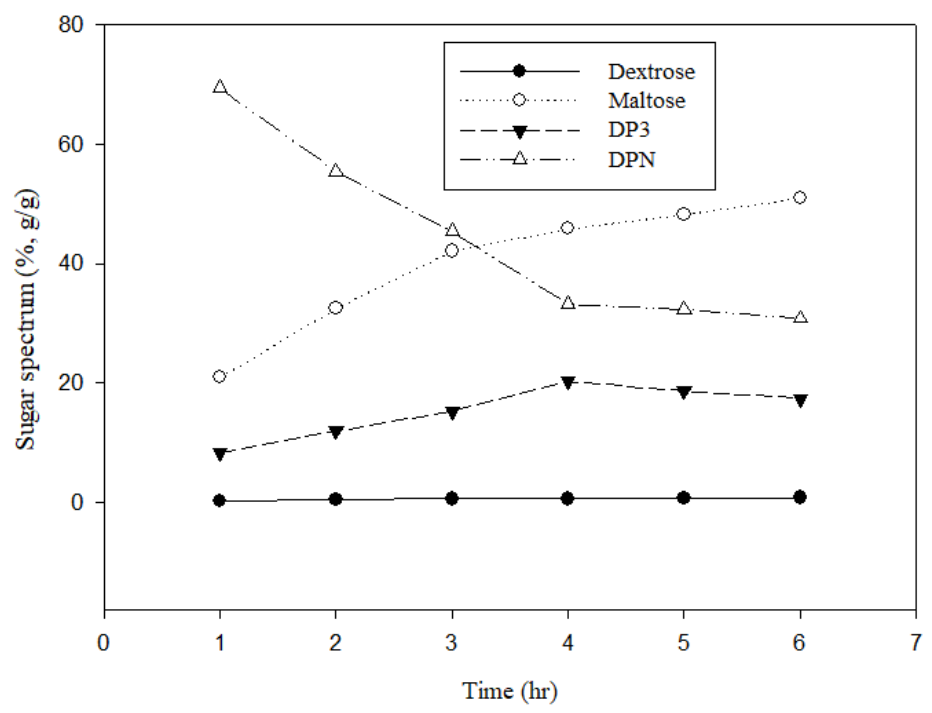

(b) Run 10: $\mathrm{E} 1=0.20 \mathrm{ml}+\mathrm{E} 2=0.05 \mathrm{ml}$

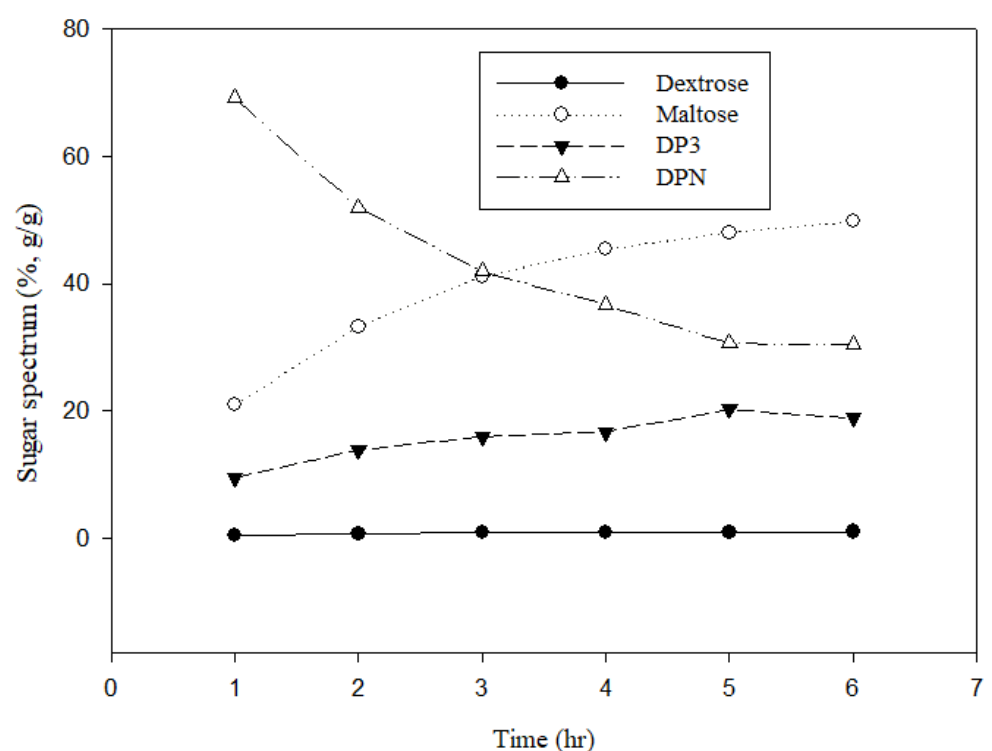

(d) Run 12: $\mathrm{E} 1=0.20 \mathrm{ml}+\mathrm{E} 2=0.09 \mathrm{ml}$

Figure 8. Different E2 concentrations. (a): $0.03 \mathrm{ml}$, (b): $0.05 \mathrm{ml}$, (c): $0.07 \mathrm{ml}$ and (d): $0.09 \mathrm{ml}$ mixed with E1:0.20 ml 


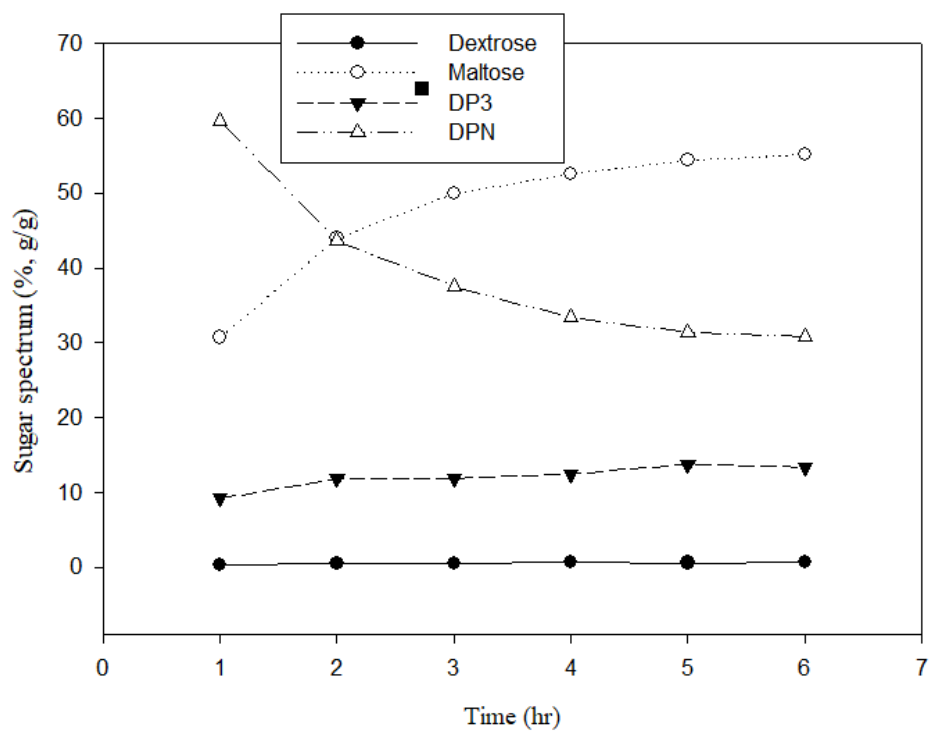

(a) Run 13: $\mathrm{E} 1=0.25 \mathrm{ml}+\mathrm{E} 2=0.03 \mathrm{ml}$

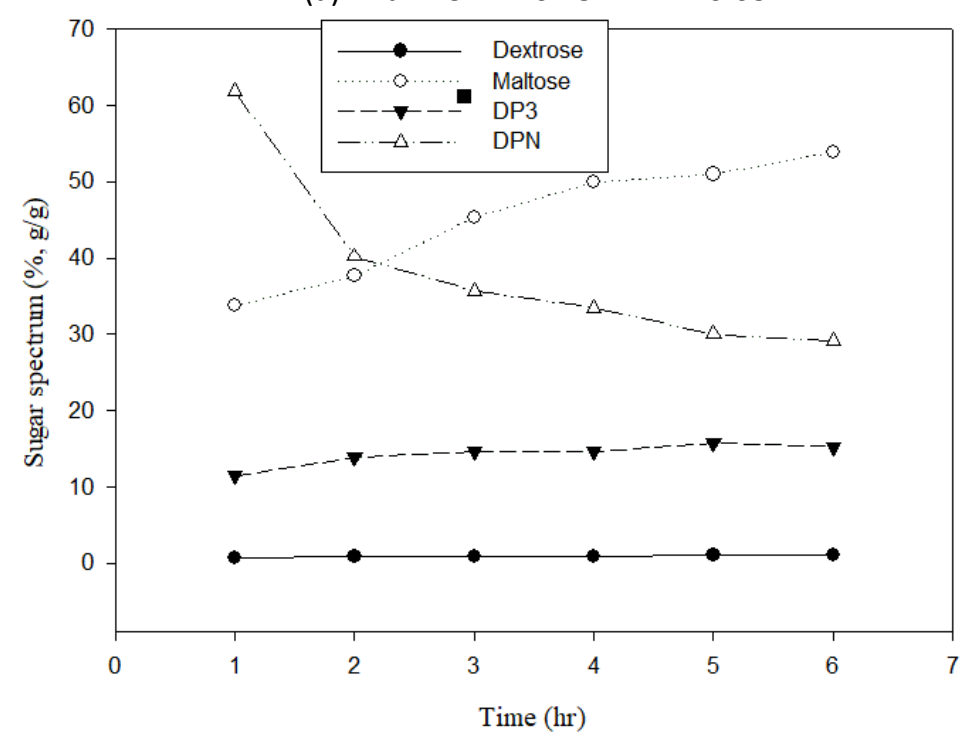

(c) Run 15: $\mathrm{E} 1=0.25 \mathrm{ml}+\mathrm{E} 2=0.07 \mathrm{ml}$

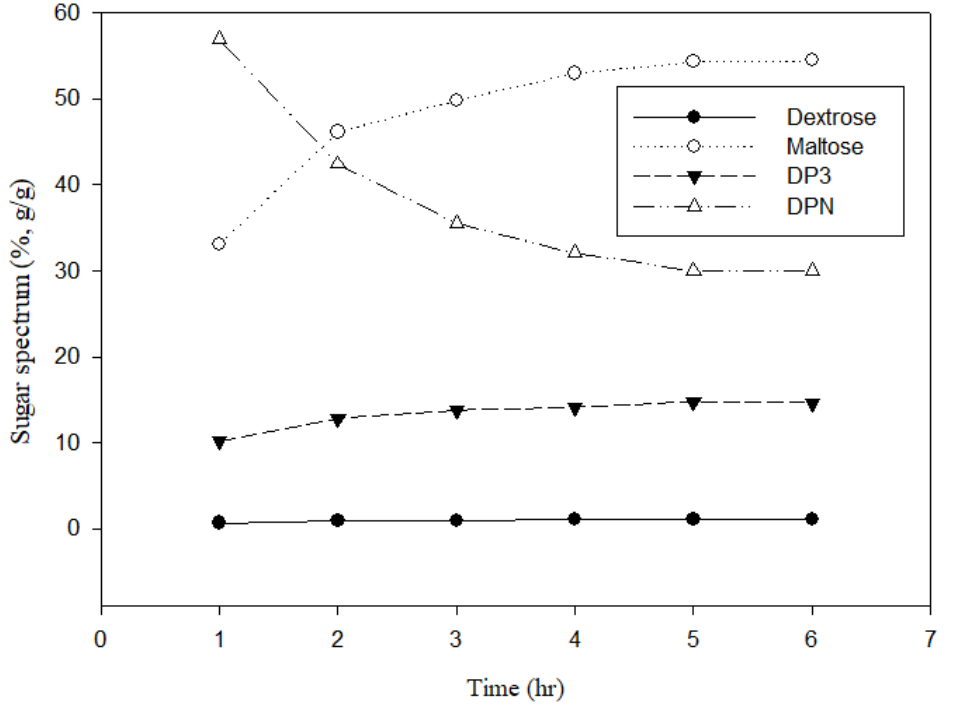

(b) Run 14: $\mathrm{E} 1=0.25 \mathrm{ml}+\mathrm{E} 2=0.05 \mathrm{ml}$

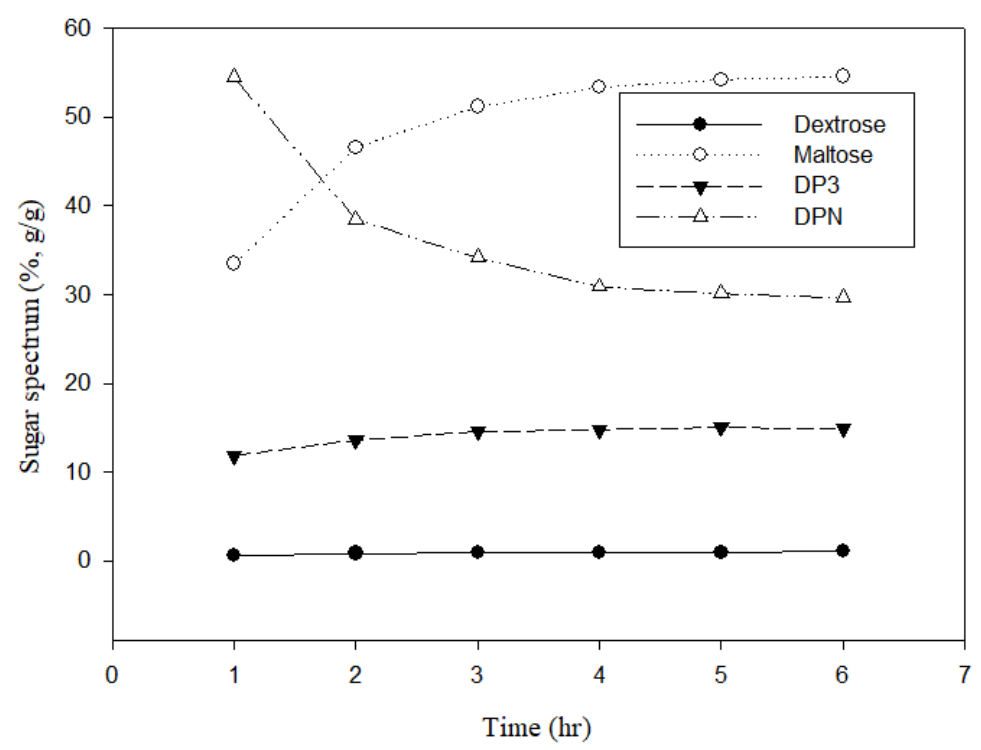

(d) Run 16: E1=0.25 ml +E2=0.09 ml

Figure 9. Different E2 concentrations. (a): $0.03 \mathrm{ml}$, (b): $0.05 \mathrm{ml}$, (c): $0.07 \mathrm{ml}$ and (d): $0.09 \mathrm{ml}$ mixed with E1: $0.25 \mathrm{ml}$ 
Change in brix and $\mathrm{pH}$ during the starch conversion reaction

To follow the changes in Brix and $\mathrm{pH}$ values, their results were also analyzed. According to the statistical analysis, it was found that E1, E2, E1xE2 had a significant $(P \leq 0.05)$ effect on Brix and $\mathrm{pH}$ according to the Duncan test. Time, E2xTime, E1xTime, E1xE2xTime had no significant $(P>0.05)$ effect on the values.

\section{Process control and dynamic parameters (process} gain, process time constant and dead time)

To determine the process control variables, two methods (Methods I and II) were used (Marlin, 2000; Smith, 1972; Ziegler and Nichols, 1942). Process gain (Kp, the effect of the change in the input to the change in the output), process time constant $(\tau$, "how fast" the process will respond after it starts moving) and dead time ( $\theta$, "how long" it will take a process to react to a change in the control output) were determined and they were used to analyze the dynamics of the starch conversion (Table 3).

According to the process gain values $(\mathrm{Kp})$, both methods (Methods I and II) use the same formula, so their values were the same. Gain value means that the changes in the enzyme concentrations (change in input) affect the change in the amount of dextrose, maltose, DP3 and DPN (as the change in output). According to the results, there was a positive gain for dextrose, maltose and DP3. DPN had negative gain concerning the enzyme concentrations. The maximum process gains were obtained at Run 1, 13, 9 and 13 for dextrose, maltose, DP3 and DPN, respectively. According to these results, the amount of E2 needed to be 0.03 $\mathrm{ml}$ at each maximum value of all Runs.

Another important result was obtained such as; when the amount of E2 was increased at constant E1, the gain values decreased systematically for maltose, DP3 and DPN. This result is very important during the controlling process and the automation of the system.

It should be noted that the control of the starch conversion system can be made by using these gain values. Especially, if small or big changes are required for dextrose, maltose, DP3 and DPN, these small or big gain values can be used to determine the enzyme concentrations of E1 and E2.

Another effective usage of these data is to determine the processing time constant and dead time for the starch conversion stage. At the required gain or conversion values, the processing time constant and dead time can be determined from the results obtained. As a note, in the literature, Method II values for both processing time constant and dead time are preferred in the process control studies. Practically, in the process control system, there are processes, transmitters, controllers and actuators. The values obtained from the study can be used for the controller during the process control as dynamic parameters. According to gain, process time constant and dead time values, the controller will send a signal to the actuator to manipulate the enzyme dosage pump during the starch conversion process.

The processing time constant defines "how fast" the process will respond after it starts moving, as explained previously. Therefore, when the enzyme is added, the processing time constant value gives the how fast the starch conversion occurs during the reaction. According to Table 3, the processing time constant at maximum gain values was $1.009,24.005,6.608$ and $|-31.912|$ hours for dextrose, maltose, DP3 and DPN, respectively. It was higher for maltose and DPN than dextrose and DPN. 
Table 3. Process control and dynamic parameters (process gain, process time constant and dead time)

\begin{tabular}{|c|c|c|c|c|c|c|c|c|c|c|c|c|c|c|c|c|c|c|c|c|c|}
\hline \multirow{2}{*}{ Comp. } & \multirow{2}{*}{$\begin{array}{l}\text { Run } \\
\text { No. }\end{array}$} & \multicolumn{2}{|c|}{$\begin{array}{l}\text { Enzyme } \\
\text { conc. }\end{array}$} & \multicolumn{4}{|c|}{ Model Parameters } & \multicolumn{6}{|c|}{ Model 1} & \multicolumn{8}{|c|}{ Model 2} \\
\hline & & E1 & E2 & a & b & Xo & R2 & $\begin{array}{l}\text { Smax } \\
\text { (g/hr) }\end{array}$ & $\begin{array}{c}\Delta \\
\text { (g) }\end{array}$ & $\begin{array}{c}\delta \\
(\mathrm{ml})\end{array}$ & $\begin{array}{c}\Theta \\
\text { (hr) }\end{array}$ & $\begin{array}{c}\tau \\
(\mathrm{hr})\end{array}$ & $\begin{array}{c}\mathrm{Kp} \\
(\mathrm{g} / \mathrm{ml})\end{array}$ & $\begin{array}{c} \\
(\mathrm{g} / \mathrm{hr})\end{array}$ & $\begin{array}{c}\Delta \Delta \\
\text { (g) }\end{array}$ & $\begin{array}{c}\mathrm{t} \\
(63 \%) \\
\end{array}$ & $\begin{array}{c}t \\
(28 \%)\end{array}$ & $\begin{array}{c}\delta \\
(\mathrm{ml})\end{array}$ & $\begin{array}{c}\Theta \\
(\mathrm{hr})\end{array}$ & $\begin{array}{c}\tau \\
(\mathrm{hr})\end{array}$ & $\begin{array}{c}\mathrm{Kp} \\
(\mathrm{g} / \mathrm{ml})\end{array}$ \\
\hline & 1 & 0.10 & 0.03 & 2.424 & 1.28 & 1.905 & 0.952 & 0.473 & 1.922 & 0.030 & 1 & 4.066 & 64.067 & 0.473 & 1.922 & 1.211 & 0.538 & 0.03 & 0.202 & 1.009 & 64.067 \\
\hline & 2 & 0.10 & 0.05 & 1.689 & 4.805 & 6.135 & 0.92 & 0.739 & 1.375 & 0.050 & 1 & 1.860 & 27.500 & 0.739 & 1.375 & 0.866 & 0.385 & 0.05 & 0.144 & 0.722 & 27.500 \\
\hline & 3 & 0.10 & 0.07 & 5.145 & 2.635 & 5.642 & 0.945 & 0.813 & 2.240 & 0.070 & 1 & 2.754 & 32.000 & 0.813 & 2.24 & 1.411 & 0.627 & 0.07 & 0.235 & 1.176 & 32.000 \\
\hline & 4 & 0.10 & 0.09 & 1.636 & 4.959 & 7.075 & 0.996 & 1.232 & 1.335 & 0.090 & 1 & 1.084 & 14.833 & 1.232 & 1.335 & 0.841 & 0.374 & 0.09 & 0.140 & 0.701 & 14.833 \\
\hline & 5 & 0.15 & 0.03 & 9.832 & 1.958 & 1.834 & 0.985 & 0.240 & 0.611 & 0.030 & 1 & 2.545 & 20.367 & 0.24 & 0.611 & 0.385 & 0.171 & 0.03 & 0.064 & 0.321 & 20.367 \\
\hline & 6 & 0.15 & 0.05 & 1.721 & 8.553 & 9.338 & 0.95 & 2.744 & 1.305 & 0.050 & 1 & 0.476 & 26.100 & 2.744 & 1.305 & 0.822 & 0.365 & 0.05 & 0.137 & 0.685 & 26.100 \\
\hline & 7 & 0.15 & 0.07 & 9.408 & 1.078 & 6.295 & 0.973 & 0.444 & 0.624 & 0.070 & 1 & 1.406 & 8.914 & 0.444 & 0.624 & 0.393 & 0.175 & 0.07 & 0.066 & 0.328 & 8.914 \\
\hline & 8 & 0.15 & 0.09 & 2.764 & 2.787 & 3.23 & 0.827 & 1.994 & 1.434 & 0.090 & 1 & 0.719 & 15.932 & 1.994 & 1.434 & 0.903 & 0.402 & 0.09 & 0.151 & 0.753 & 15.933 \\
\hline & 9 & 0.20 & 0.03 & 1.036 & 1.823 & 1.764 & 0.986 & 0.301 & 0.671 & 0.030 & 1 & 2.227 & 22.367 & 0.301 & 0.671 & 0.423 & 0.188 & 0.03 & 0.070 & 0.352 & 22.367 \\
\hline & 10 & 0.20 & 0.05 & 8.852 & 2.038 & 1.401 & 0.938 & 0.824 & 0.524 & 0.050 & 1 & 0.636 & 10.480 & 0.824 & 0.524 & 0.330 & 0.147 & 0.05 & 0.055 & 0.275 & 10.480 \\
\hline & 11 & 0.20 & 0.07 & 3.049 & 2.493 & 5.795 & 0.975 & 0.928 & 1.317 & 0.070 & 1 & 1.419 & 18.814 & 0.928 & 1.317 & 0.830 & 0.369 & 0.07 & 0.138 & 0.691 & 18.814 \\
\hline & 12 & 0.20 & 0.09 & 1.037 & 1.138 & 1.153 & 0.974 & 1.720 & 0.758 & 0.090 & 1 & 0.441 & 8.422 & 1.72 & 0.758 & 0.478 & 0.212 & 0.09 & 0.080 & 0.398 & 8.422 \\
\hline & 13 & 0.25 & 0.03 & 7.711 & 1.864 & 8.593 & 0.946 & 0.469 & 0.441 & 0.030 & 1 & 0.941 & 14.700 & 0.469 & 0.441 & 0.278 & 0.123 & 0.03 & 0.046 & 0.232 & 14.700 \\
\hline & 14 & 0.25 & 0.05 & 1.08 & 7.509 & 6.602 & 0.979 & 2.318 & 0.789 & 0.050 & 1 & 0.340 & 15.780 & 2.318 & 0.789 & 0.497 & 0.221 & 0.05 & 0.083 & 0.414 & 15.780 \\
\hline & 15 & 0.25 & 0.07 & 9.986 & 8.705 & 5.613 & 0.958 & 0.820 & 0.696 & 0.070 & 1 & 0.848 & 9.943 & 0.82 & 0.696 & 0.438 & 0.195 & 0.07 & 0.073 & 0.365 & 9.943 \\
\hline & 16 & 0.25 & 0.09 & 9.908 & 7.463 & 6.261 & 0.985 & 1.105 & 0.725 & 0.090 & 1 & 0.656 & 8.056 & 1.105 & 0.725 & 0.457 & 0.203 & 0.09 & 0.076 & 0.381 & 8.056 \\
\hline \multirow{16}{*}{ 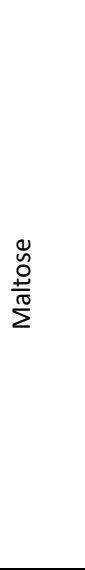 } & 1 & 0.10 & 0.03 & 4.637 & 1.470 & 2.634 & 0.991 & 7.114 & 35.156 & 0.030 & 1 & 4.942 & 1171.860 & 7.114 & 35.156 & 22.148 & 9.844 & 0.030 & 3.691 & 18.457 & 1171.860 \\
\hline & 2 & 0.10 & 0.05 & 3.893 & 9.864 & 1.691 & 0.991 & 1.230 & 32.614 & 0.050 & 1 & 26.510 & 652.272 & 1.230 & 32.614 & 20.547 & 9.132 & 0.050 & 3.424 & 17.122 & 652.272 \\
\hline & 3 & 0.10 & 0.07 & 3.896 & 1.144 & 2.010 & 0.992 & 0.888 & 32.148 & 0.070 & 1 & 36.212 & 459.256 & 0.888 & 32.148 & 20.253 & 9.001 & 0.070 & 3.376 & 16.878 & 459.256 \\
\hline & 4 & 0.10 & 0.09 & 3.853 & 9.831 & 1.604 & 0.985 & 1.144 & 31.880 & 0.090 & 1 & 27.872 & 354.220 & 1.144 & 31.880 & 20.084 & 8.926 & 0.090 & 3.347 & 16.737 & 354.220 \\
\hline & 5 & 0.15 & 0.03 & 4.867 & 8.269 & 1.378 & 0.982 & 1.368 & 40.931 & 0.030 & 1 & 29.924 & 1364.380 & 1.368 & 40.931 & 25.787 & 11.461 & 0.030 & 4.298 & 21.489 & 1364.380 \\
\hline & 6 & 0.15 & 0.05 & 4.326 & 8.795 & 1.481 & 0.982 & 0.849 & 36.099 & 0.050 & 1 & 42.509 & 721.988 & 0.849 & 36.099 & 22.743 & 10.108 & 0.050 & 3.790 & 18.952 & 721.988 \\
\hline & 7 & 0.15 & 0.07 & 4.970 & 6.269 & 1.123 & 0.983 & 1.319 & 42.574 & 0.070 & 1 & 32.272 & 608.201 & 1.319 & 42.574 & 26.822 & 11.921 & 0.070 & 4.470 & 22.351 & 608.201 \\
\hline & 8 & 0.15 & 0.09 & 4.327 & 7.468 & 1.316 & 0.989 & 0.818 & 36.777 & 0.090 & 1 & 44.948 & 408.631 & 0.818 & 36.777 & 23.169 & 10.298 & 0.090 & 3.862 & 19.308 & 408.631 \\
\hline & 9 & 0.20 & 0.03 & 4.685 & 8.250 & 1.453 & 0.982 & 1.030 & 39.763 & 0.030 & 1 & 38.608 & 1325.433 & 1.030 & 39.763 & 25.051 & 11.134 & 0.030 & 4.175 & 20.876 & 1325.433 \\
\hline & 10 & 0.20 & 0.05 & 4.917 & 8.186 & 1.425 & 0.987 & 1.056 & 41.778 & 0.050 & 1 & 39.553 & 835.564 & 1.056 & 41.778 & 26.320 & 11.698 & 0.050 & 4.387 & 21.934 & 835.564 \\
\hline & 11 & 0.20 & 0.07 & 4.714 & 8.928 & 1.458 & 0.982 & 0.906 & 38.882 & 0.070 & 1 & 42.938 & 555.461 & 0.906 & 38.882 & 24.496 & 10.887 & 0.070 & 4.083 & 20.413 & 555.461 \\
\hline & 12 & 0.20 & 0.09 & 4.824 & 7.912 & 1.369 & 0.987 & 1.090 & 41.050 & 0.090 & 1 & 37.663 & 456.111 & 1.090 & 41.050 & 25.862 & 11.494 & 0.090 & 4.310 & 21.551 & 456.111 \\
\hline & 13 & 0.25 & 0.03 & 5.293 & 5.143 & 9.421 & 0.982 & 1.249 & 45.724 & 0.030 & 1 & 36.618 & 1524.133 & 1.249 & 45.724 & 28.806 & 12.803 & 0.030 & 4.801 & 24.005 & 1524.133 \\
\hline & 14 & 0.25 & 0.05 & 5.236 & 4.104 & 8.286 & 0.984 & 1.016 & 47.976 & 0.050 & 1 & 47.225 & 959.526 & 1.016 & 47.976 & 30.225 & 13.433 & 0.050 & 5.038 & 25.188 & 959.526 \\
\hline & 15 & 0.25 & 0.07 & 4.994 & 6.047 & 8.752 & 0.929 & 0.857 & 45.284 & 0.070 & 1 & 52.815 & 646.910 & 0.857 & 45.284 & 28.529 & 12.679 & 0.070 & 4.755 & 23.774 & 646.910 \\
\hline & 16 & 0.25 & 0.09 & 5.277 & 4.033 & 8.258 & 0.987 & 1.157 & 49.415 & 0.090 & 1 & 42.694 & 549.056 & 1.157 & 49.415 & 31.131 & 13.836 & 0.090 & 5.189 & 25.943 & 549.056 \\
\hline \multirow{9}{*}{ ñ } & 1 & 0.10 & 0.03 & 2.012 & 2.413 & 1.238 & 0.998 & 1.947 & 10.354 & 0.030 & 1 & 5.317 & 345.127 & 1.947 & 10.354 & 6.523 & 2.899 & 0.030 & 1.087 & 5.436 & 345.127 \\
\hline & 2 & 0.10 & 0.05 & 1.857 & 1.334 & 6.011 & 0.988 & 1.552 & 11.104 & 0.050 & 1 & 7.156 & 222.072 & 1.552 & 11.104 & 6.995 & 3.109 & 0.050 & 1.166 & 5.829 & 222.072 \\
\hline & 3 & 0.10 & 0.07 & 1.941 & 1.800 & 8.429 & 0.995 & 0.821 & 10.938 & 0.070 & 1 & 13.315 & 156.253 & 0.821 & 10.938 & 6.891 & 3.063 & 0.070 & 1.148 & 5.742 & 156.253 \\
\hline & 4 & 0.10 & 0.09 & 1.971 & 1.147 & 5.476 & 0.989 & 1.431 & 12.107 & 0.090 & 1 & 8.460 & 134.526 & 1.431 & 12.107 & 7.628 & 3.390 & 0.090 & 1.271 & 6.356 & 134.526 \\
\hline & 5 & 0.15 & 0.03 & 2.159 & 3.101 & 1.711 & 0.917 & 0.601 & 9.875 & 0.030 & 1 & 16.426 & 329.157 & 0.601 & 9.875 & 6.221 & 2.765 & 0.030 & 1.037 & 5.184 & 329.157 \\
\hline & 6 & 0.15 & 0.05 & 1.762 & 1.149 & 3.526 & 0.995 & 1.308 & 9.972 & 0.050 & 1 & 7.625 & 199.430 & 1.308 & 9.972 & 6.282 & 2.792 & 0.050 & 1.047 & 5.235 & 199.430 \\
\hline & 7 & 0.15 & 0.07 & 1.932 & 8.763 & 6.052 & 0.861 & 1.538 & 13.012 & 0.070 & 1 & 8.461 & 185.880 & 1.538 & 13.012 & 8.197 & 3.643 & 0.070 & 1.366 & 6.831 & 185.880 \\
\hline & 8 & 0.15 & 0.09 & 2.026 & 1.431 & 6.808 & 0.960 & 0.634 & 12.387 & 0.090 & 1 & 19.528 & 137.637 & 0.634 & 12.387 & 7.804 & 3.468 & 0.090 & 1.301 & 6.503 & 137.637 \\
\hline & 9 & 0.20 & 0.03 & 2.295 & 2.399 & 2.152 & 0.928 & 0.683 & 12.586 & 0.030 & 1 & 18.428 & 419.533 & 0.683 & 12.586 & 7.929 & 3.524 & 0.030 & 1.322 & 6.608 & 419.533 \\
\hline
\end{tabular}


Continued

\begin{tabular}{|c|c|c|c|c|c|c|c|c|c|c|c|c|c|c|c|c|c|c|c|c|c|}
\hline \multirow{9}{*}{ Comp. } & \multirow{2}{*}{$\begin{array}{l}\text { Run } \\
\text { No. }\end{array}$} & \multicolumn{2}{|c|}{$\begin{array}{l}\text { Enzyme } \\
\text { conc. }\end{array}$} & \multicolumn{4}{|c|}{ Model Parameters } & \multicolumn{6}{|c|}{ Model 1} & \multicolumn{8}{|c|}{ Model 2} \\
\hline & & E1 & E2 & a & b & Xo & R2 & $\begin{array}{l}\text { Smax } \\
\text { (g/hr) }\end{array}$ & $\begin{array}{c}\Delta \Delta \\
\text { (g) }\end{array}$ & $\begin{array}{c}\delta \\
(\mathrm{ml})\end{array}$ & $\begin{array}{c}\Theta \\
(\mathrm{hr})\end{array}$ & $\begin{array}{c}\tau \\
\text { (hr) }\end{array}$ & $\begin{array}{c}\mathrm{Kp} \\
(\mathrm{g} / \mathrm{ml})\end{array}$ & $\begin{array}{c}\mathrm{S} \\
(\mathrm{g} / \mathrm{hr})\end{array}$ & $\begin{array}{c}\Delta \Delta \\
\text { (g) }\end{array}$ & $\begin{array}{c}t \\
(63 \%)\end{array}$ & $\begin{array}{c}t \\
(28 \%)\end{array}$ & $\begin{array}{c}\delta \\
(\mathrm{ml})\end{array}$ & $\begin{array}{c}\Theta \\
(\mathrm{hr})\end{array}$ & $\begin{array}{c}\tau \\
\text { (hr) }\end{array}$ & $\begin{array}{c}\mathrm{Kp} \\
(\mathrm{g} / \mathrm{ml})\end{array}$ \\
\hline & 10 & 0.20 & 0.05 & 1.974 & 1.416 & 1.109 & 0.896 & 1.114 & 13.169 & 0.050 & 1 & 11.820 & 263.372 & 1.114 & 13.169 & 8.296 & 3.687 & 0.050 & 1.383 & 6.914 & 263.372 \\
\hline & 11 & 0.20 & 0.07 & 2.242 & 2.149 & 1.545 & 0.984 & 0.955 & 12.753 & 0.070 & 1 & 13.357 & 182.187 & 0.955 & 12.753 & 8.034 & 3.571 & 0.070 & 1.339 & 6.695 & 182.187 \\
\hline & 12 & 0.20 & 0.09 & 2.045 & 1.635 & 9.648 & 0.965 & 1.115 & 12.523 & 0.090 & 1 & 11.227 & 139.141 & 1.115 & 12.523 & 7.889 & 3.506 & 0.090 & 1.315 & 6.574 & 139.141 \\
\hline & 13 & 0.25 & 0.03 & 1.377 & 1.620 & -3.522 & 0.960 & 0.521 & 5.963 & 0.030 & 1 & 11.439 & 198.777 & 0.521 & 5.963 & 3.757 & 1.670 & 0.030 & 0.626 & 3.131 & 198.777 \\
\hline & 14 & 0.25 & 0.05 & 1.483 & 1.193 & -6.024 & 0.993 & 1.323 & 7.211 & 0.050 & 1 & 5.451 & 144.228 & 1.323 & 7.211 & 4.543 & 2.019 & 0.050 & 0.757 & 3.786 & 144.228 \\
\hline & 15 & 0.25 & 0.07 & 1.534 & 9.412 & -1.580 & 0.987 & 1.123 & 7.760 & 0.070 & 1 & 6.910 & 110.851 & 1.123 & 7.760 & 4.889 & 2.173 & 0.070 & 0.815 & 4.074 & 110.851 \\
\hline & 16 & 0.25 & 0.09 & 1.490 & 8.248 & -6.867 & 0.997 & 0.966 & 7.291 & 0.090 & 1 & 7.548 & 81.006 & 0.966 & 7.291 & 4.593 & 2.041 & 0.090 & 0.766 & 3.828 & 81.006 \\
\hline \multirow{16}{*}{ ż } & 1 & 0.10 & 0.03 & 2.095 & -5.021 & -1.819 & 0.992 & -8.754 & -51.939 & 0.030 & 1 & 5.933 & -1731.303 & -8.754 & -51.939 & -32.722 & -14.543 & 0.030 & -5.454 & -27.268 & -1731.303 \\
\hline & 2 & 0.10 & 0.05 & 2.457 & -7.074 & -4.016 & 0.974 & 1.323 & -49.907 & 0.050 & 1 & -37.711 & -998.138 & 1.323 & -49.907 & -31.441 & -13.974 & 0.050 & -5.240 & -26.201 & -998.138 \\
\hline & 3 & 0.10 & 0.07 & 1.146 & -7.431 & -3.629 & 0.993 & 0.887 & -50.025 & 0.070 & 1 & -56.415 & -714.649 & 0.887 & -50.025 & -31.516 & -14.007 & 0.070 & -5.253 & -26.263 & -714.649 \\
\hline & 4 & 0.10 & 0.09 & 2.928 & -6.913 & -4.055 & 0.955 & 1.204 & -49.771 & 0.090 & 1 & -41.339 & -553.016 & 1.204 & -49.771 & -31.356 & -13.936 & 0.090 & -5.226 & -26.130 & -553.016 \\
\hline & 5 & 0.15 & 0.03 & 4.064 & -5.435 & -3.362 & 0.969 & 1.137 & -59.094 & 0.030 & 1 & -51.973 & -1969.800 & 1.137 & -59.094 & -37.229 & -16.546 & 0.030 & -6.205 & -31.024 & -1969.800 \\
\hline & 6 & 0.15 & 0.05 & 3.384 & -5.779 & -3.467 & 0.969 & 0.951 & -56.664 & 0.050 & 1 & -59.583 & -1133.276 & 0.951 & -56.664 & -35.698 & -15.866 & 0.050 & -5.950 & -29.748 & -1133.276 \\
\hline & 7 & 0.15 & 0.07 & 8.417 & -4.265 & -2.957 & 0.918 & 1.315 & -68.445 & 0.070 & 1 & -52.049 & -977.784 & 1.315 & -68.445 & -43.120 & -19.165 & 0.070 & -7.187 & -35.934 & -977.784 \\
\hline & 8 & 0.15 & 0.09 & 4.756 & -5.303 & -3.367 & 0.933 & 0.753 & -60.003 & 0.090 & 1 & -79.737 & -666.699 & 0.753 & -60.003 & -37.802 & -16.801 & 0.090 & -6.300 & -31.502 & -666.699 \\
\hline & 9 & 0.20 & 0.03 & 2.202 & -5.353 & -2.964 & 0.981 & 1.000 & -59.924 & 0.030 & 1 & -59.925 & -1997.460 & 1.000 & -59.924 & -37.752 & -16.779 & 0.030 & -6.292 & -31.460 & -1997.460 \\
\hline & 10 & 0.20 & 0.05 & 3.346 & -4.952 & -2.957 & 0.978 & 0.978 & -62.077 & 0.050 & 1 & -63.481 & -1241.546 & 0.978 & -62.077 & -39.109 & -17.382 & 0.050 & -6.518 & -32.591 & -1241.546 \\
\hline & 11 & 0.20 & 0.07 & 2.837 & -5.231 & -3.036 & 0.985 & 0.999 & -60.161 & 0.070 & 1 & -60.213 & -859.441 & 0.999 & -60.161 & -37.901 & -16.845 & 0.070 & -6.317 & -31.584 & -859.441 \\
\hline & 12 & 0.20 & 0.09 & 4.318 & -4.858 & -3.030 & 0.974 & 1.098 & -62.552 & 0.090 & 1 & -56.945 & -695.017 & 1.098 & -62.552 & -39.407 & -17.514 & 0.090 & -6.568 & -32.840 & -695.017 \\
\hline & 13 & 0.25 & 0.03 & 8.325 & -4.695 & -3.266 & 0.899 & 1.097 & -60.785 & 0.030 & 1 & -55.421 & -2026.157 & 1.097 & -60.785 & -38.294 & -17.020 & 0.030 & -6.382 & -31.912 & -2026.157 \\
\hline & 14 & 0.25 & 0.05 & 9.664 & -4.478 & -3.186 & 0.886 & 1.033 & -62.094 & 0.050 & 1 & -60.086 & -1241.886 & 1.033 & -62.094 & -39.119 & -17.386 & 0.050 & -6.520 & -32.600 & -1241.886 \\
\hline & 15 & 0.25 & 0.07 & 9.254 & -4.395 & -3.099 & 0.898 & 1.021 & -64.961 & 0.070 & 1 & -63.641 & -928.014 & 1.021 & -64.961 & -40.925 & -18.189 & 0.070 & -6.821 & -34.105 & -928.014 \\
\hline & 16 & 0.25 & 0.09 & 1.116 & -4.338 & -3.156 & 0.847 & 1.010 & -61.840 & 0.090 & 1 & -61.204 & -687.114 & 1.010 & -61.840 & -38.959 & -17.315 & 0.090 & -6.493 & -32.466 & -687.114 \\
\hline
\end{tabular}

E1: $\beta$-amylase, E2: $\alpha$-amylase, a and b: input variables, Xo: initial input variable, $\mathrm{R}^{2:}$ Regression value, Kp: Process gain, $\delta:$ magnitude of the input change, $\Delta:$ the magnitude

of the steady-state change in the output, S: the maximum slope of the output-versus-time plot, $\theta$ : intercept of maximum slope with initial value, $\tau$ is absolute. The negative values show the trend of the change. 
There is a great need to develop their use in a different form and various industries like medical, food. Moreover, some alternative technological changes develop the enzyme's practicability of cost-effectiveness. There is a different solution in the literature, for example, surface functionalization of calixarene has been used for the effectiveness of immobilization of $\alpha$ amylase. $\alpha$ amylase was covalently immobilized with a glutaraldehyde-containing amino group functionalized calixarene. This technique was studied by Veesar et al. (2015). In this technique, imide bonds are formed between amino groups on the protein aldehyde groups on the calixarene surface. The result of different preparation conditions on the immobilized alpha-amylase process like immobilization time, enzyme concentration, temperature and $\mathrm{pH}$ were determined by these researchers. The result of hydrogen ion concentration and temperature changes on the activity of free and immobilized alpha-amylase was researched by using starch. The optimum reaction temperature and $\mathrm{pH}$ value were catalyzed by the immobilized alpha-amylase at $25^{\circ} \mathrm{C}$ and $7{ }^{\circ} \mathrm{C}$, respectively in the enzymatic conversion. Compared to the free enzyme, immobilized alpha-amylase retained $85 \%$ of its original activity, also showed thermal stability and excellent durability.

Further, another research was made by Talekar et al. (2013) that a tri-enzyme biocatalyst which name is combi-CLEAs with starch hydrolytic activity was set from pullulanase, alpha-amylase and glucoamylase. These enzymes are aggregating enzymes with ammonium sulfate which are cross bonding formed aggregates for $4.5 \mathrm{~h}$ with $40 \mathrm{mM}$ glutaraldehyde. The biocatalyst was identified. Cross-linking and precipitant type were examined. Optimum $\mathrm{pH}$ and temperature changes from 6 to 7 and from 65 to $75{ }^{\circ} \mathrm{C}$ were examined after the co-immobilization of enzymes. Afterwards starch hydrolysis reaction in batch, separate CLEAs, combi-CLEAs and free enzyme mixtures were used for examining 60, 100 and $40 \%$ conversions. Furthermore, thermal stability of enzymes were increased with co- immobilization. Lastly, the catalytic activity of enzymes is preserved during starch hydrolysis up to 5 cycles without performance change in combiCLEAs.

In the literature, there are also some different operations to determine their effect on starch conversion. Buckow et al. (2007) were studied in the barley malt, the effect of temperature and high hydrostatic pressure on the stability and catalytic activity of alpha-amylase were observed. Inactivation operations with alpha-amylase which include with and without calcium ions were done under 0.1-800 $\mathrm{MPa}$ pressure-and $30-75{ }^{\circ} \mathrm{C}$ temperature range. $\mathrm{Ca}^{2+}$ ions have a stabilizing effect on the enzyme at all pressure-temperature ranges. According to kinetic analysis, aberrations of simple first-order reactions were based on the existence of isoenzyme fractions.

\section{Conclusion}

Maltose syrup is a value-added product and it is characterized by having $50 \%$ of maltose content and less than $5 \%$ of dextrose. The exact sugar spectrum of maltose syrup varies from one producer to another and varies with the demand of customers and the experience of operators. Due to this fluctuation, the optimum enzyme concentration is accurately not determined during production.

The starch conversion process of the maltose syrup production was analyzed to determine the optimum enzyme concentrations, process control parameters and dynamics. Practically, in industrial production, the fluctuation in the enzyme and time consumption increase the maltose syrup production cost. The ideal operational and control parameters were determined for the desired product specification

In this study, maltose concentration is obtained as $50 \%$ in this study by using; $0.15 \mathrm{ml}$ E1+0.03 $\mathrm{ml}$ E2 enyzmes at sixth hour, $0.15 \mathrm{ml}$ $\mathrm{E} 1+0.07 \mathrm{ml} \mathrm{E2}$ enyzmes at sixth hour, $0.2 \mathrm{ml}$ E1+0.03 $\mathrm{ml} \mathrm{E2} \mathrm{enyzmes} \mathrm{at} \mathrm{sixth} \mathrm{hour,} 0.2 \mathrm{ml}$ $\mathrm{E} 1+0.05 \mathrm{ml} \mathrm{E} 2$ enyzmes at sixth hour, $0.2 \mathrm{ml}$ E1+0.09 $\mathrm{ml}$ E2 enyzmes at sixth hour and $0.25 \mathrm{ml}$ 
E1+0.03 $\mathrm{ml}$ E2 enzymes at third hour. As a result, optimum concentration of enzyme is $0.20 \mathrm{ml}$ E1+0.05 $\mathrm{ml}$ E2 enzymes at sixth hour.

\section{Acknowledgements}

Some of the experiments were carried out at the Beşan Nişasta A.Ş., Gaziantep, Turkey. We thank most sincerely Uluğbey High Technology Application and Research Center (ULUTEM) for all the support. Additionally, for the guidance and support for the improvement of the manuscript, we thank most sincerely Prof. Dr. Tülay EZER.

Conflict of Interest: The authors declare no conflict of interest.

Author Contribution: Sema Nur Çinçik made preparation of manuscript, experimental analysis and data analysis. Fatih Balcı made experimental design, statistical analysis, coordination and management of the paper. Mustafa Bayram made the process control studies and overall evaluation of the data.

\section{References}

Altmann, W. (2005). Practical Process Control for Engineers and Technicians. Burlington, MA: Elsevier.

AOAC. (1990). Official methods of analysis (15 th $\mathrm{Edn})$. Association of Official Analytical Chemists. Arlington, VA, USA.

BeMiller, J. N., \& Huber, K. C. (2007). Carbohydrates. In S. Damodaran, Parkin, K.L., Fennema, O.R. (Ed.), In Fennema's Food Chemistry (pp. 83-151). CRC Press: Boca Raton, FL, USA.

Blanchard, P. H. (1992). Technology of corn wet milling and associated processes. Amsterdam: Elsevier.

Buckow, R., Weiss, U., Heinz, V., \& Knorr, D. (2007). Stability and catalytic activity of alpha-amylase from barley malt at different pressure-temperature conditions. Biotechnology and Bioengineering, 97(1), 1-11. DOI: 10.1002/bit.21209

CRA. (2010). Dextrose Equivalent (Lane and Eynon). http://corn.org/publications/industry-

resources/analytical-methods/analytical-methodstoc/: Corn Refiners Association.

Eke-Ejiofor, J. (2015). Functional Properties of Starches, Physico-Chemical And Rheological Properties of Glucose Syrup Made From Cassava And Different Potato Varieties. International Journal of Recent Scientific Research. Vol. 6, Issue, 6, pp.4400-4406.

Gough, C. R., Rivera-Galletti A., Cowan D. A., Cruz D. S. \& Hu X. (2020). Protein and Polysaccharide-Based Fiber
Materials Generated from Ionic Liquids: A Review. Molecules. 25, DOI:10.3390/molecules25153362

Hull, P. (2010). Glucose syrups: Technology and Applications. New York: John Wiley \& Sons.

Johnson, R., Padmaja, G., \& Moorthy, S. (2009). Comparative production of glucose and high fructose syrup from cassava and sweet potato roots by direct conversion techniques. Innovative Food Science \& Emerging Technologies, 10(4), 616-620.

Kim, T. H., Nghiem, N. P., Taylor, F., \& Hicks, K. B. (2011). Consolidated Conversion of Hulled Barley into Fermentable Sugars Using Chemical, Thermal, and Enzymatic (CTE) Treatment. Applied Biochemistry and Biotechnology, 164(4), 534-545. DOI: 10.1007/s12010-010-9155-1

Lin, Q. L., Xiao, H. X., Liu, G. Q., Liu, Z. H., Li, L. H., \& Yu, F. X. (2013). Production of Maltose Syrup by Enzymatic Conversion of Rice Starch. Food and Bioprocess Technology, 6(1), 242-248. DOI: 10.1007/s11947011-0681-9

MacGregor, A. W., Bazin, S. L., Macri, L. J., \& Babb, J. V. (1999). Modelling the contribution of alpha-amylase, beta-amylase and limit dextrinase to starch degradation during mashing. Journal of Cereal Science, 29(2), 161-169. DOI: 10.1006/jcrs.1998.0233

Marlin, T. E. (2000). Process Control: Designing processes and control systems for dynamic performance (2 ed.). USA: McGraw Hill.

Norman, R. J., Masters, L., Milner, C. R., Wang, J. X., \& Davies, M. J. (2001). Relative risk of conversion from normoglycaemia to impaired glucose tolerance or non-insulin dependent diabetes mellitus in polycystic ovarian syndrome. Human Reproduction, 16(9), 1995-1998.

Öktem, A., \& Toprak A. (2013). Çukurova koşullarında bazı atdişi mısır (Zea mays L. indentata) Genotiplerinin verim ve Morfolojik Özelliklerinin Belirlenmesi. Harran Tarım ve Gıda Bilimleri Dergisi, Cilt 17, Sayı 4, 2013, 15 - 24

Piddocke, M. P., Kreisz, S., Heldt-Hansen, H. P., Nielsen, K. F., \& Olsson, L. (2009). Physiological characterization of brewer's yeast in high-gravity beer fermentations with glucose or maltose syrups as adjuncts. Applied Microbiology and Biotechnology, 84, 453-464.

Polat A., Karaaslan, M., \& Gürsöz, S. (2016). Siverek Yöresinde Yetiştirilen Kızıl Banki ve Bastık Kabarcık Üzüm Çeşitlerinin Organik Asit ve Şeker İçeriklerinin Belirlenmesi Üzerine Bir Araştırma. Harran Tarım ve Gıda Bilimleri Dergisi, 20(3): 166-174.

Pontoh, J., \& Low, N. H. (1995). Glucose syrup production from Indonesian palm and cassava starch. Food Research International, 28(4), 379-385.

Smith, C. L., (1972). Digital computer process control. Scranton Intext Educational Publishers.

Synowiecki, J. (2007). The use of starch processing enzymes in the food industry. In J. Polaina, MacCabe, A.P. (Ed.), In Industrial Enzymes. Dordrecht, The Netherlands: Springer.

Talekar, S., Pandharbale, A., Ladole, M., Nadar, S., Mulla, M., Japhalekar, K., Arage, D. (2013). Carrier free coimmobilization of alpha amylase, glucoamylase and pullulanase as combined cross-linked enzyme 
aggregates (combi-CLEAs): A tri-enzyme biocatalyst with one pot starch hydrolytic activity. Bioresource Technology, 147, 269-275. DOI: 10.1016/j.biortech.2013.08.035

United State Patent Norman et.al Patent No. US 6,287,826, B1, Date. September 11,2001

van der Maarel, M. J., \& Leemhuis, H. (2013). Starch modification with microbial alphaglucanotransferase enzymes. Carbohydrate Polymers, 93(1), 116-121. DOI: 10.1016/j.carbpol.2012.01.065
Veesar, I. A., Solangi, I. B., \& Memon, S. (2015). Immobilization of alpha-amylase onto a calix 4 arene derivative: Evaluation of its enzymatic activity. Bioorganic Chemistry, 60, 58-63. DOI: 10.1016/j.bioorg.2015.04.007

Zeeman, S. C., Kossmann, J., \& Smith, A. M. (2010). Starch: its metabolism, evolution, and biotechnological modification in plants. Annual review of plant biology, 61, 209-234.

Ziegler, J. G., \& Nichols, N. B. (1942). Optimum settings for automatic controllers. trans. ASME, 64(11). 